\title{
54. RIFTING AND SUBSIDENCE OF THE NORTHERN CONTINENTAL MARGIN OF THE BAY OF BISCAY
}

\author{
L. Montadert, Institut Français du Pétrole, BP 311 Rueil-Malmaison, 92506 France \\ D.G. Roberts, Institute of Oceanographic Sciences, Wormley, Godalming, Surrey, U.K. \\ O. De Charpal, Institut Français du Pétrole, BP 311 Rueil-Malmaison, 92506 France \\ and \\ P. Guennoc, Centre Océanologique de Bretagne, BP 337, 29273 Brest, France
}

\begin{abstract}
In the northeast Atlantic, DSDP drilling results, combined with intensive geophysical surveys, permit a proposed model of the structural evolution of a starved, passive continental margin. Environment and tectonics of the rifting phase have been established. Active rifting took place in Early Cretaceous time in a pre-existing marine basin in contrast to many subaerial rift systems. The overall tectonic style is characterized by a series of tilted fault blocks bounded in many cases by listric faults. The rotation of the blocks $\left(20-30^{\circ}\right)$ along listric faults reduced the thickness of the upper continental crust from 6 to $8 \mathrm{~km}$ to 4 to $5 \mathrm{~km}$. Close to the near horizontal base of the listric faults, a strong horizontal reflector corresponding to the 6.3 to $4.9 \mathrm{~km} / \mathrm{s}$ refraction interface has been interpreted as the boundary between the upper brittle and the lower ductile continental crusts. The Moho discontinuity, $25 \mathrm{~km}$ deep in the vicinity of the shelf break, is $12 \mathrm{~km}$ deep in the lower part of the margin. In this area the ductile part of the crust (6.3 $\mathrm{km} / \mathrm{s}$ ) is only $3 \mathrm{~km}$ thick.

Drill, dredge, and seismic reflection data allow reconstruction of the topography of the sea floor at the end of rifting in Aptian time. In the axis of the rift system, submarine troughs $2.5 \mathrm{~km}$ deep existed. The mechanism of rifting is discussed. The thinning of the continental crust cannot be explained by the 10 to 15 per cent of extension estimated for the upper brittle part. It is suggested that the ductile part of the crust is thinned by creep in response to tension in the continental plate.

Knowing the topography of the sea floor at the end of rifting and the present depth of the Aptian datum, the absolute amount of subsidence can be determined on a transect of the margin after the beginning of accretion (late Aptian time). This value decreases continuously from the oceanic/ continental crust boundary $(4000 \mathrm{~m})$ to the shelf break. For each point of the margin, the subsidence versus time curve is an exponential, the time constant of which increases with depth. The post-rifting subsidence is essentially an isostatic adjustment to cooling of the lithosphere in which the continental crust previously has been thinned during the rifting process.
\end{abstract}

\section{INTRODUCTION}

The northern margin of the Bay of Biscay was selected for drilling because it is a unique area in the Atlantic Ocean where drilling easily could reach layers deposited during the early stages of the evolution of a passive continental margin.

All of the objectives at the three sites drilled, 400, 401, and 402 , were not attained but, complemented by intensive multichannel seismic reflection profiling and by dredgings, a model of evolution of a passive continental margin can be proposed.

The geological structure of the Bay of Biscay and of its continental margins is complex because it results not only from rifting and divergence of Europe, Iberia and North America, but also from convergence between Europe, Iberia and Africa. The age and kinematics of the opening of the Bay of Biscay are still a matter of controversy. If one accepts identification of anomalies 33-34 following Cande and Kristoffersen (1977), and if these anomalies are also recognized in the axis of the Bay (triple junction during anomalies 33-34), the creation of oceanic crust in Biscay ceased before anomalies 33-34 or terminated shortly thereafter. The beginning of accretion most probably was within Albian/Aptian time. One thus must distinguish the northern Bay of Biscay margin and its onshore prolongation into the Aquitaine Basin (Montadert et al., 1974), which remained essentially stable during its entire history, and the north Spanish margin which was active almost from the opening of the Bay of Biscay (Cenomanian movements recorded in the Pyrennées) and until at least Eocene-Oligocene time.

Bathymetry of the stable northern Biscay margin clearly shows different provinces (Figures 1 and 2) (Berthois and Brenot, 1966; Berthois et al., 1968). 


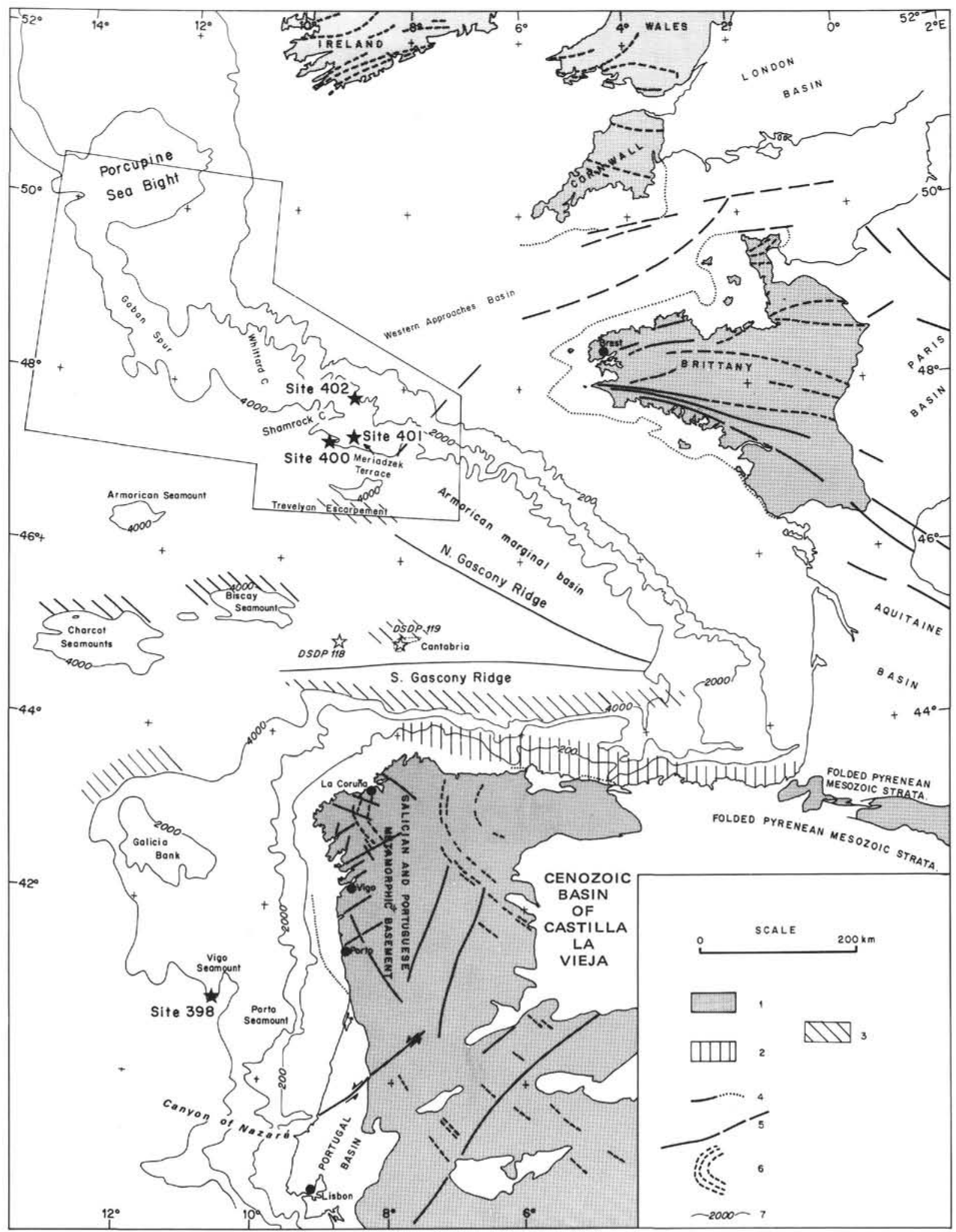

Figure 1. Generalized physiography of southwestern European coast and margin, and location of Leg 48 area (North Biscay). 1 = Hercynian ranges and Paleozoic basins, $2=$ Undersea area affected by Pyrenean tectonic movements, $3=$ Tectonized area in the abyssal plain north of Spain, $4=$ Boundaries of inshore basins. Blank areas inland represent the Mesozoic and Cenozoic basins, 5=Main fractured zones and faults, $6=$ Main Hercynian fold trends, $7=$ Contours of 200, 2000, and 4000 meter bathymetric intervals. After data from the large-scale geological maps of the countries, the maps of the English channel, Armorican shelf, and Portuguese shelf. 


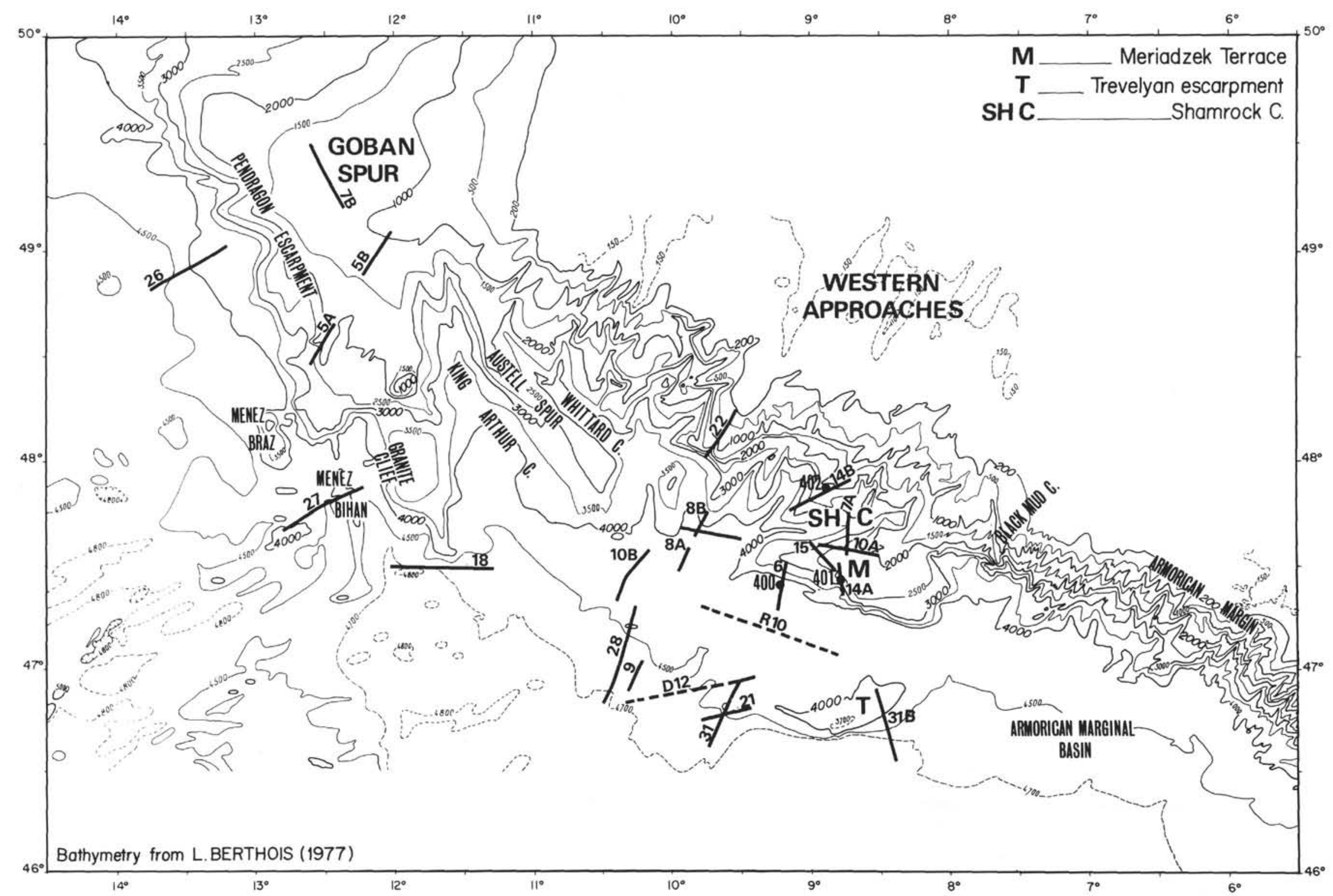

Figure 2. Detailed bathymetry of north Biscay margin from Berthois (1977). Solid lines and numbers indicate seismic reflection profiles presented in this paper and figure number. Dotted lines represent refraction profiles. 
1) The Armorican margin from Aquitaine to the Western Approaches Basin is narrow and steep and is bounded on the southwest by the deep Armorican marginal basin with its thick Mesozoic/Cenozoic section. On the shelf, it is Hercynian basement covered by a thin wedge of sediments.

2) The Western Approaches margin is broader, with several large topographic features, e.g., the Meriadzek Terrace, the Trevelyan escarpment, and Shamrock Canyon. It intersects the northeast-southwest-trending Western Approaches Mesozoic/Cenozoic Basin on the shelf. Its southeast boundary with the Armorican margin is sharp near the Black Mud Canyon and is controlled by a northeastsouthwest fault zone known also on the shelf.

3) The Goban Spur margin has a different physiography with a relatively shallow (above $2000 \mathrm{~m}$ ), broad smooth rise, deepening abruptly along the Pendragon escarpment. It intersects a basement high in the prolongation of Cornwall. The connection with the Western Approaches margin is marked by several topographic features such as the Granite Cliff and the Austell Spur which are separated by large northwest-southeast-trending canyons.

4) The Porcupine Sea Bight is a depression containing a thick Mesozoic/Cenozoic section in a basin intersected by the margin.

The area considered in this paper corresponds to the Western Approaches margin, where Sites 400, 401, and 402 were drilled, and the Goban Spur margin. Its detailed bathymetry by Berthois is shown in Figure 2 .

Previous published seismic reflection data in this area are few. Single-channel profiles and multichannel profiles (Montadert et al., 1971, 1974) have shown the existence of horst and graben structures containing Cenozoic and Mesozoic sediments. To prepare DSDP Leg 48 drilling sites, French institutions (Institut Français du Pétrole, CNEXO, CEPM) made $3600 \mathrm{~km}$ of multichannel seismic profiles. Following the leg, these institutions carried out a new survey with $1300 \mathrm{~km}$ of multichannel seismic profiles completed by high resolution multichannel seismic profiles on the three sites. The Institute of Oceanographic Sciences (U.K.) also made about $2000 \mathrm{~km}$ of multichannel seismic profiles in this area. The coverage is presented in Figure 3.

\section{STRATIGRAPHY}

The following section is devoted mainly to the seismic stratigraphy supported by borehole and dredge data.

\section{Acoustic Stratigraphy}

The seismic sections show, in most cases, two principal formations distinguished on the basis of their acoustic character and structural features.

The upper formation is a layered, relatively undisturbed sedimentary sequence that rests on an irregular acoustic "basement" which may be either diffractive or layered and dipping. The sedimentary cover infills depressions in the basement and drapes the highs (Figure 4); it is thicker in the depressions than on the basement highs where the series is condensed and incomplete. There is thus a major unconformity between the basement and the recent sedimentary cover; in some areas however, the upper sedimentary formation is almost conformable with the layered sequences of the basement.
The sedimentary cover comprises four main units numbered, downwards from the sea floor, Formations 1 to 4 .

\section{Acoustic Basement}

The basement is distinguished from overlying sediments either by its diffractive character or by dipping reflectors. Folding is present locally (Devonian, Carboniferous ?). A strong reflector defines the basement surface and is characterized by considerable relief consisting of sharp crests, undulations, and flat horizontal surfaces (Figures 4, 5, and 6). The basement appears to be divided by faults into blocks (horsts and half-grabens) of different heights, frequently tilted along rotational faults (Figure 6). Where the basement is composed of sediments, their thickness may reach $2 \mathrm{~s}$, or more than $3 \mathrm{~km}$, assuming a mean sound velocity of 3.5 $\mathrm{km} / \mathrm{s}$. The dipping layers and faults show that fracturing and displacement occurred prior to deposition of most of the overlying sedimentary cover.

\section{Formation 4}

The first sequence deposited above the acoustical basement is moderately well layered. It infills narrow troughs between horsts or tilted blocks, or blankets the flat basement beneath the abyssal plain. Between tilted blocks, the layering is usually conformable with the structural top of the basement (the ancient erosion or deposition surface) in the lowermost part of the infill, but becomes less and less inclined upwards and may be nearly horizontal at the top of the formation (Figures 7 and 8). Obviously, sedimentation occurred during the rotation of the blocks, and deposition matched the rate of differential subsidence, resulting in horizontal layering at the end of motion. Correlation of the seismic profiles shows that Formation 4 has horizontal or slightly dipping equivalents, the degree of tilt within the sequence being variable (Figures 8 and 9). Where Formation 4 is horizontal, it is not easily distinguished from overlying Formation 3 and, in these regions (for example the Meriadzek area), a strong reflector has been taken as the boundary between the two units.

\section{Formation 3}

In most cases Formation 3 is transparent or slightly layered. It is thickest in the deep troughs between large tilted blocks (e.g., $800 \mathrm{~m}$ in Meriadzek) (Figures 10 and 11) but, in the abyssal plain, it appears as a thin continuous layer (about $200 \mathrm{~m}$ thick) overlying Formation 4 (Figures 8 and 9). Bedding may be slightly inclined in troughs and basins but dips are much less than in Formation 4 . In general, the formation appears to be absent on the structural highs, and its upper boundary lies well below the highs, but strongly condensed equivalents may be present on some high points (Site 401).

Deposition of Formation 3 infilled the depressions between the fault blocks resulting in a subdued but not totally buried topography. Dips within Formation 3 between tilted blocks reflect only differential compaction. In contrast to Formation 4, deposition took place after the basement had ceased to move actively.

\section{Formation 2}

The sequence above Formation 3 consists of several strong reflectors separated by finely layered strata. It is 


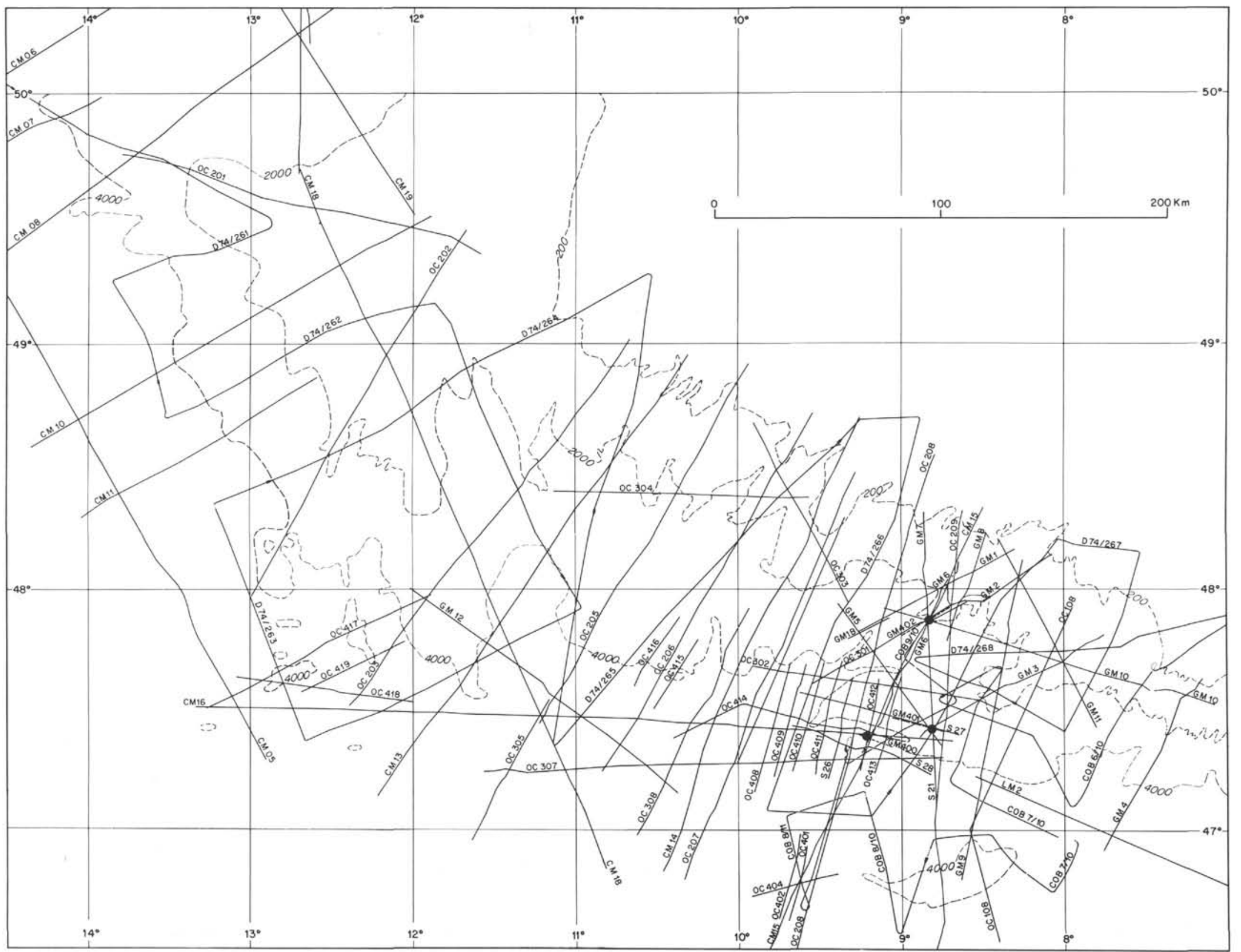




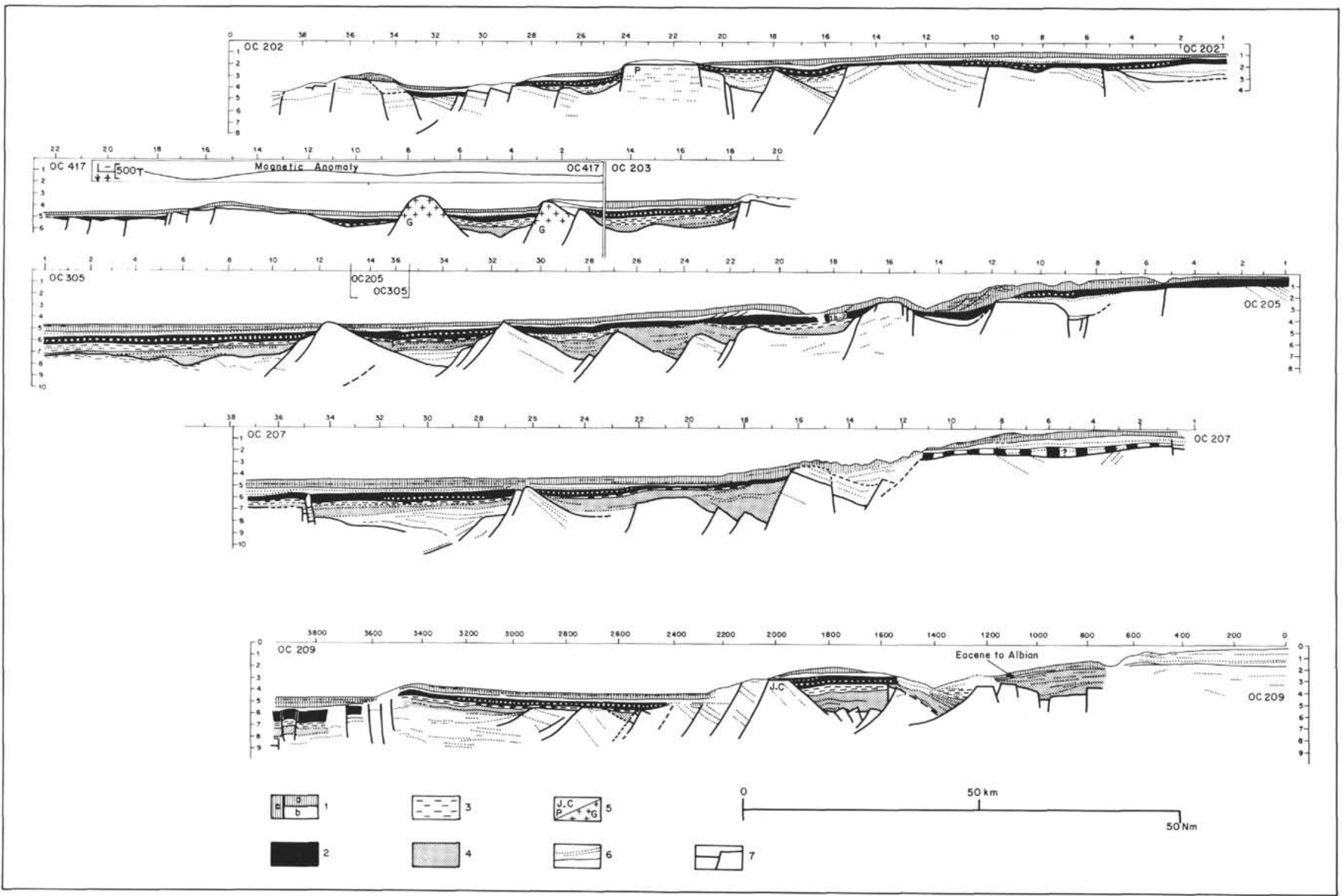

Figure 4. Depth sections across the north Biscay margin. Sections are built from seismic profiles and sound velocities derived from processing of seismic data. Unprocessed profiles OC 202, 205, and 305 were converted to depth section using velocities from nearest processed profiles. Depth below sea level in kilometers, vertical exaggeration $\times 2.5$ (see location map Figure 3). Legend: numbers 1, 2, 3, 4 refer to Formations 1, 2, 3, 4. Formation 1 has been divided into "1a" (upper member) and "1b" (lower member); " $c$ " is indifferenciated Formation 1. 5: identified acoustic basement, as J-C, limestones of Late Jurassic to Early Cretaceous age, $P$, quartzites and shales of probable Paleozoic age, G, granites and granodiorites. 6: seismic reflectors, the solid lines representing boundaries between formations and the dotted lines, other sedimentary reflectors. 7: Top of faulted basement. 


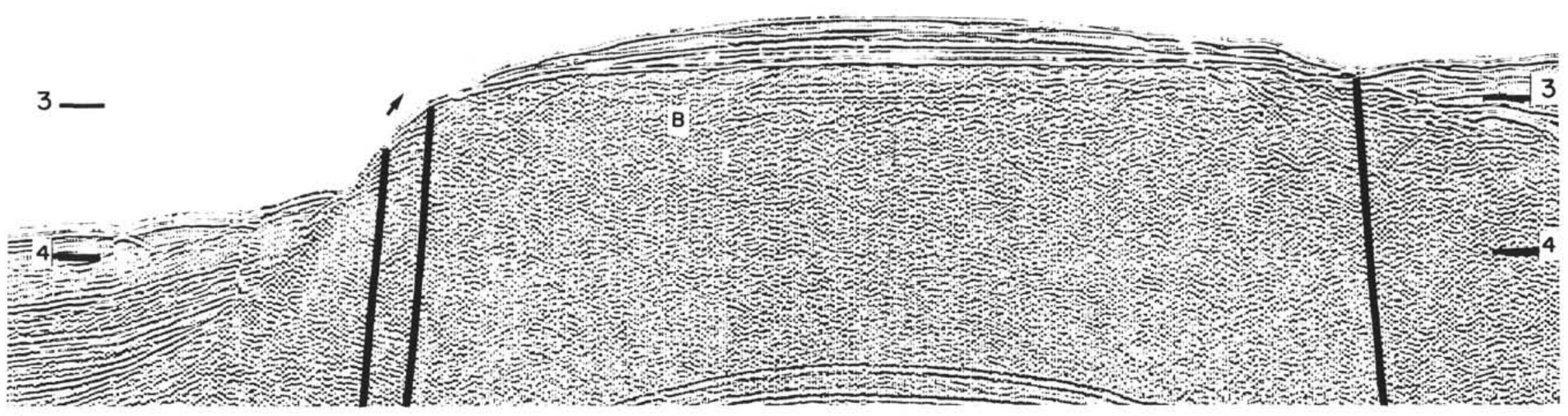

A

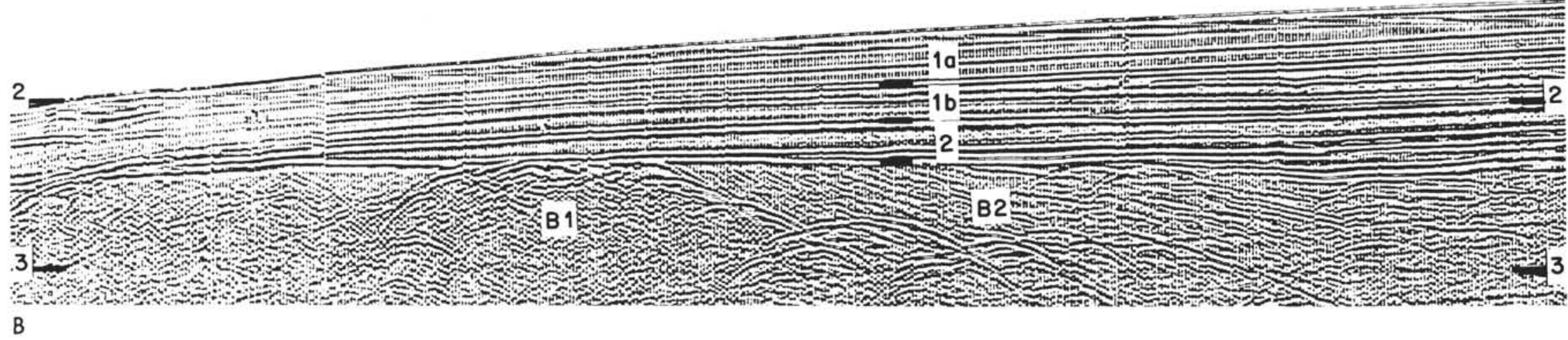

Figure 5. Types of acoustical basement. (A) Basement - nearly isotropic or with confused layering. A dredging brought up abundant samples of fine quartzites and shales of probable Paleozoic age. This basement is topped by a flat erosional surface. Arrow represents the dredging path CH $76 \mathrm{D} 18$. Profile OC 202, unprocessed. (B) Two types of acoustical basement occur under the flat erosional surface bearing the sediments. B1 seems to be an ancient nucleus of hard rocks. $B 2$ is layered and unconformable beneath the more recent sediments. Profile OC 202, unprocessed. 
$5 \mathrm{~km}$

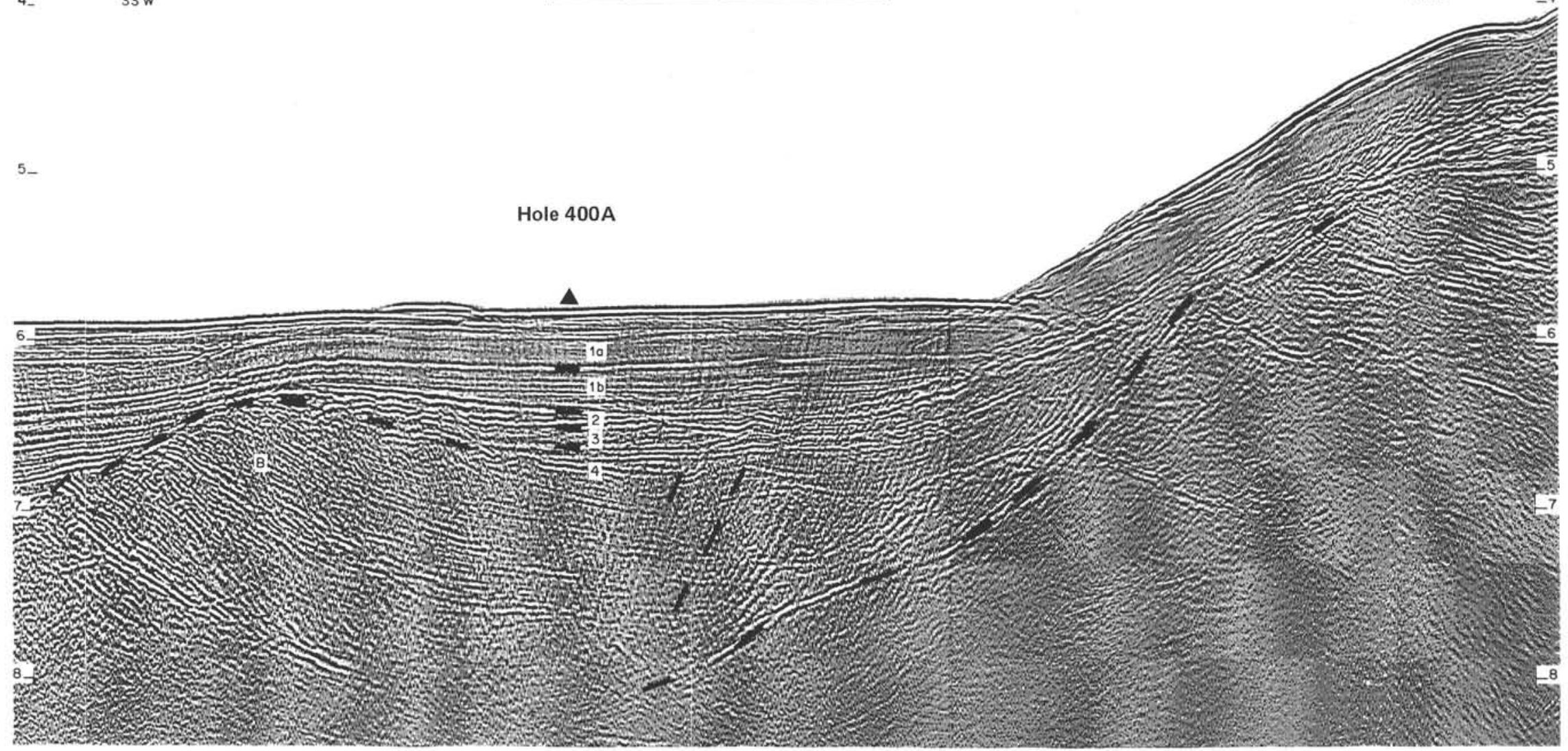

Figure 6. Acoustical basement B consists in large part of layered sedimentary rocks of probable Jurassic and early Mesozoic age. These formerly continuous layers were faulted and tilted during the Early Cretaceous rifting phase. Vertical scale in seconds, two-way travel time. Numbers $1 a, 1 b, 2,3,4$ refer to overlying sedimentary formations: Profile OC 412, migrated; Site 400. 


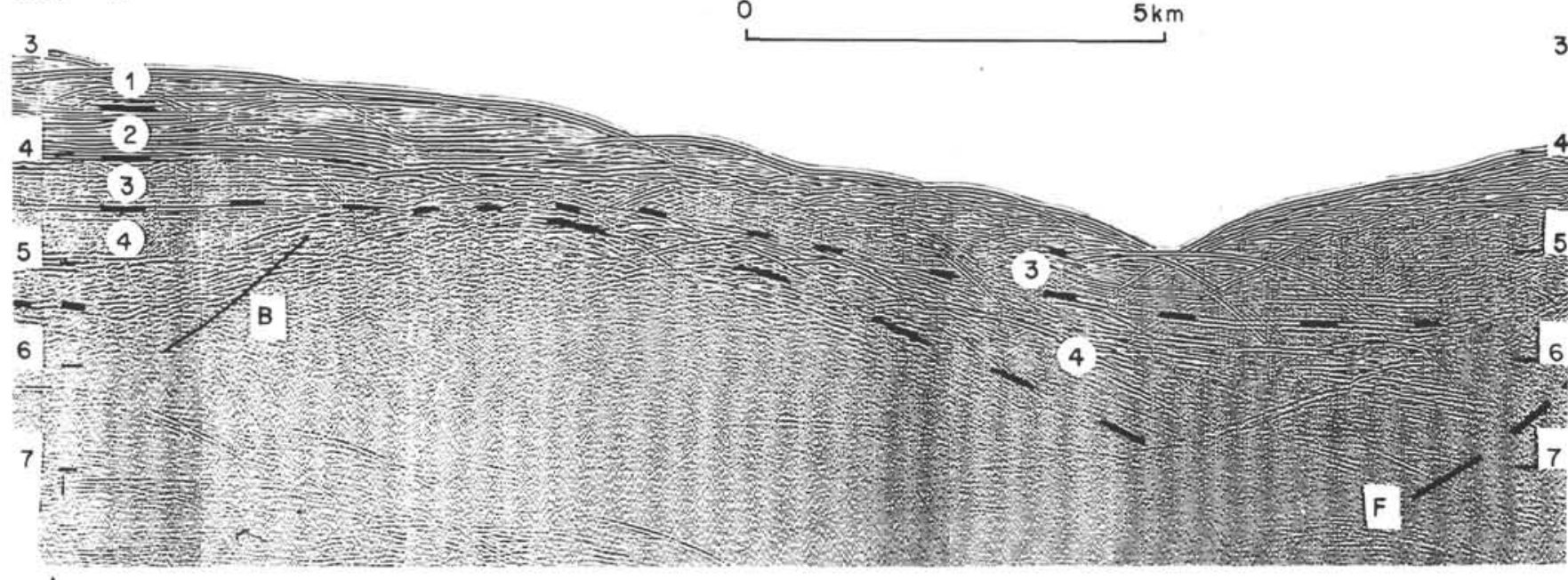

$$
\text { A }
$$

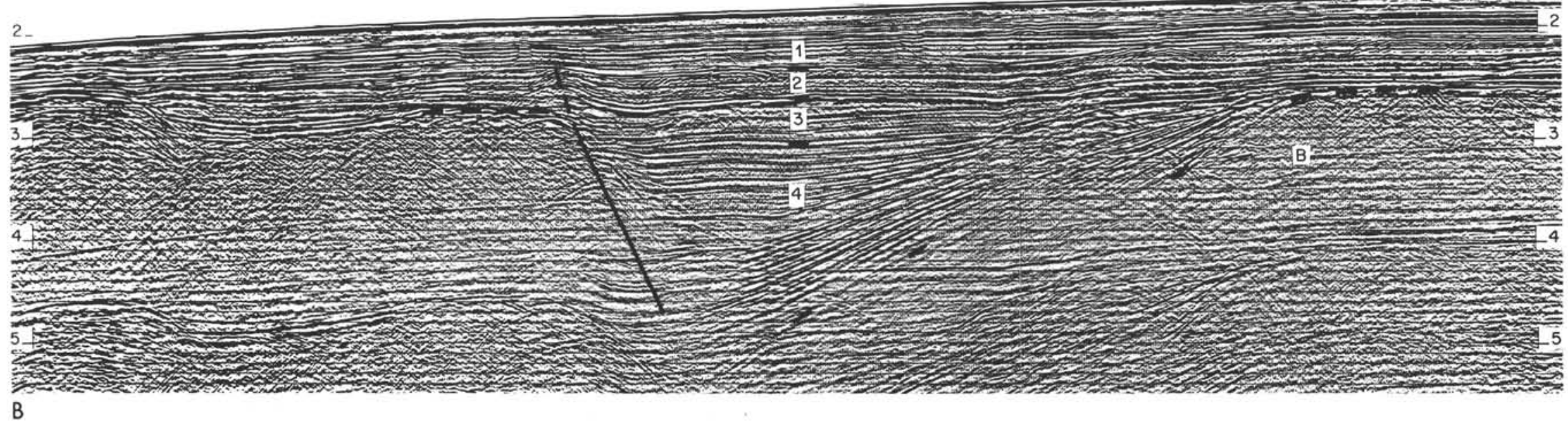

B

Figure 7. Formation 4. Examples of sedimentation synchronous with the phase of rifting. Dips varying continuously upwards indicates that the layers were deposited while the faulted blocks were actively tilting. (A) Profile OC 209 (processed) crossing the Meriadzek Terrace and the Shamrock Canyon superimposed on a half-graben. (B) Profile on Goban Spur (Profile CM 18) showing tilted blocks crests of which have been eroded during Early Cretaceous time. A rifting fault has been rejuvenated during late Eocene compression. 


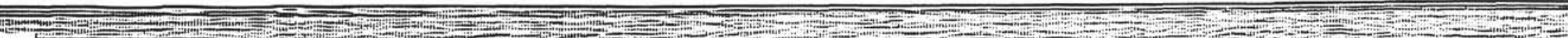

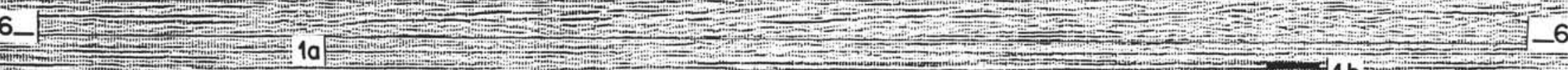

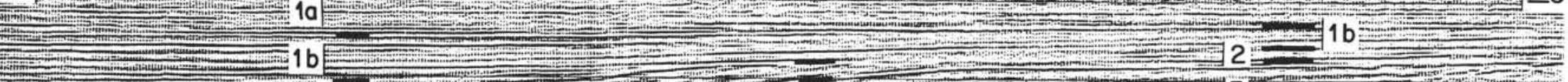

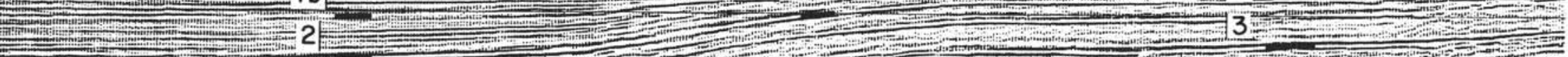

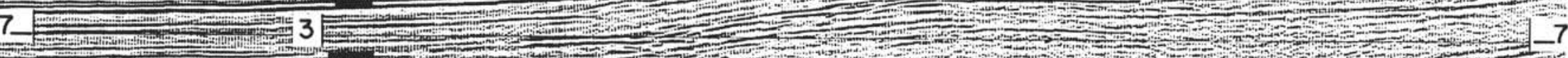

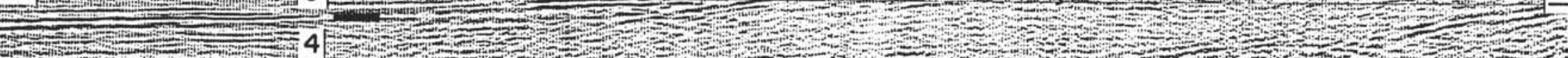

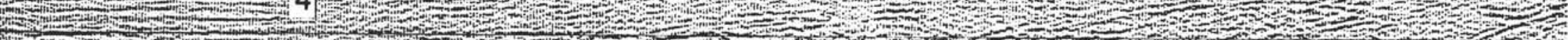

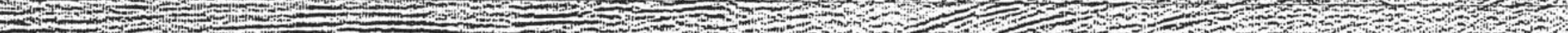

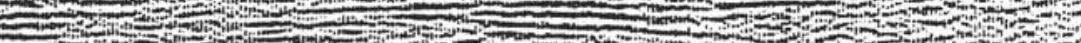

8_

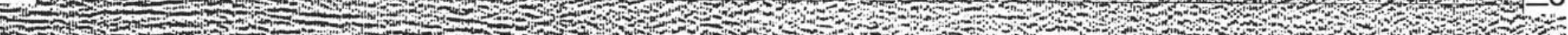

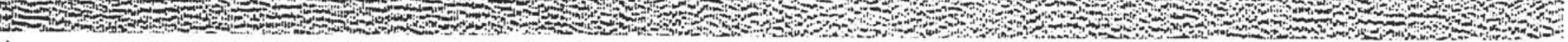

SDT

ssw

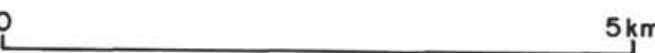

NNE

SDT

4

5

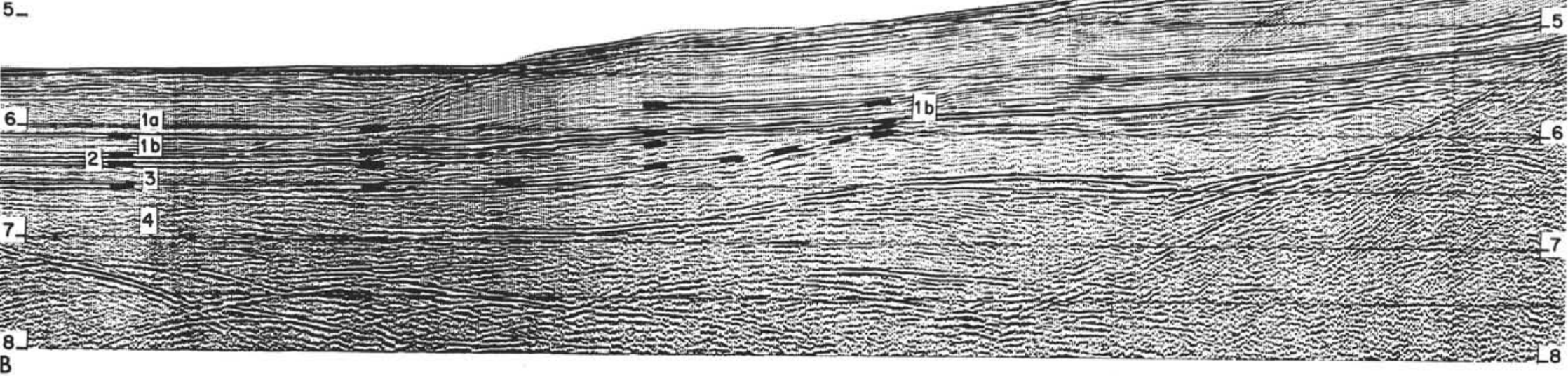

Figure 8. Sediments deposited during and after the rifting. (A) Typical sequence in the abyssal plain west of Meriadzek. Formation 3 is thin, with a sharp reflector at its base. An unconformity is clearly visible between the layered Formations 2 and $1 b$. Formation $1 a$ is weakly layered. Profile OC 207, processed. (B) In this part of Profile OC 207 at the foot of the continental slope, Formation 3 is eroded and Formation $2 b$ thins rapidly northwards. 
6.
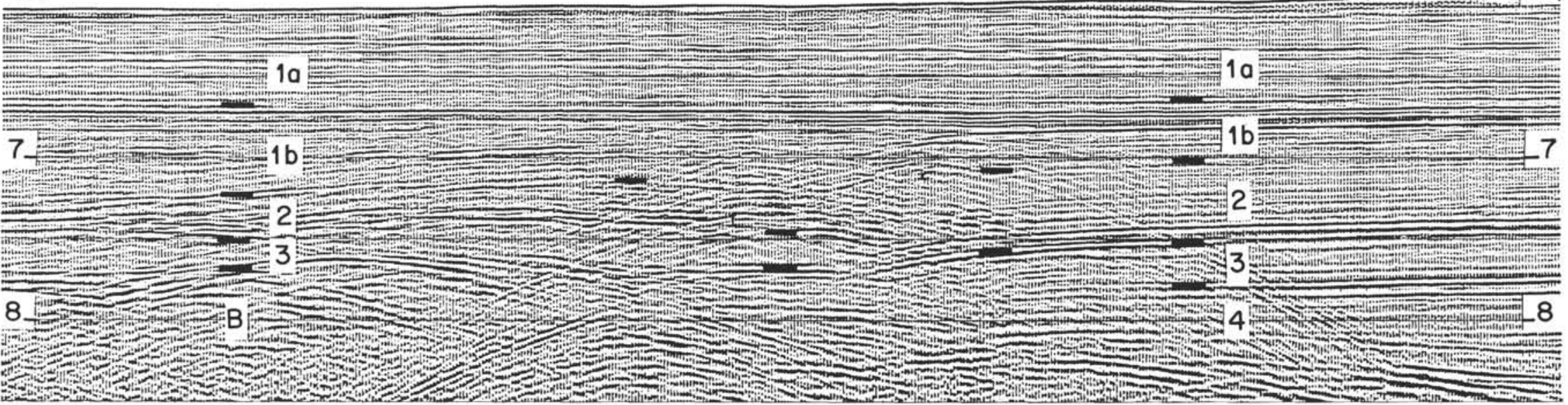

Figure 9. Lateral variations in sedimentary sequences. Abyssal plain near oceanic/continental crusts transition. In Formation 4, only the lower term may be considered as synchronous with the rifting; its upper term is nearly horizontal. Formations 2 and 1 are well developed: Formation 2 appears here weakly layered if compared with its equivalents in shallower parts of the margin. Fault with a slight throwbounds two domains: to the north, the Cretaceous series is thick; to the south, it is thinner and Formation 2 appears to thin abruptly. This fault is observed from Trevelyan to Goban Spur and is interpreted as a late Eocene strike-slip fault (see also Figure 29) Profile OC 207, processed. 
3.
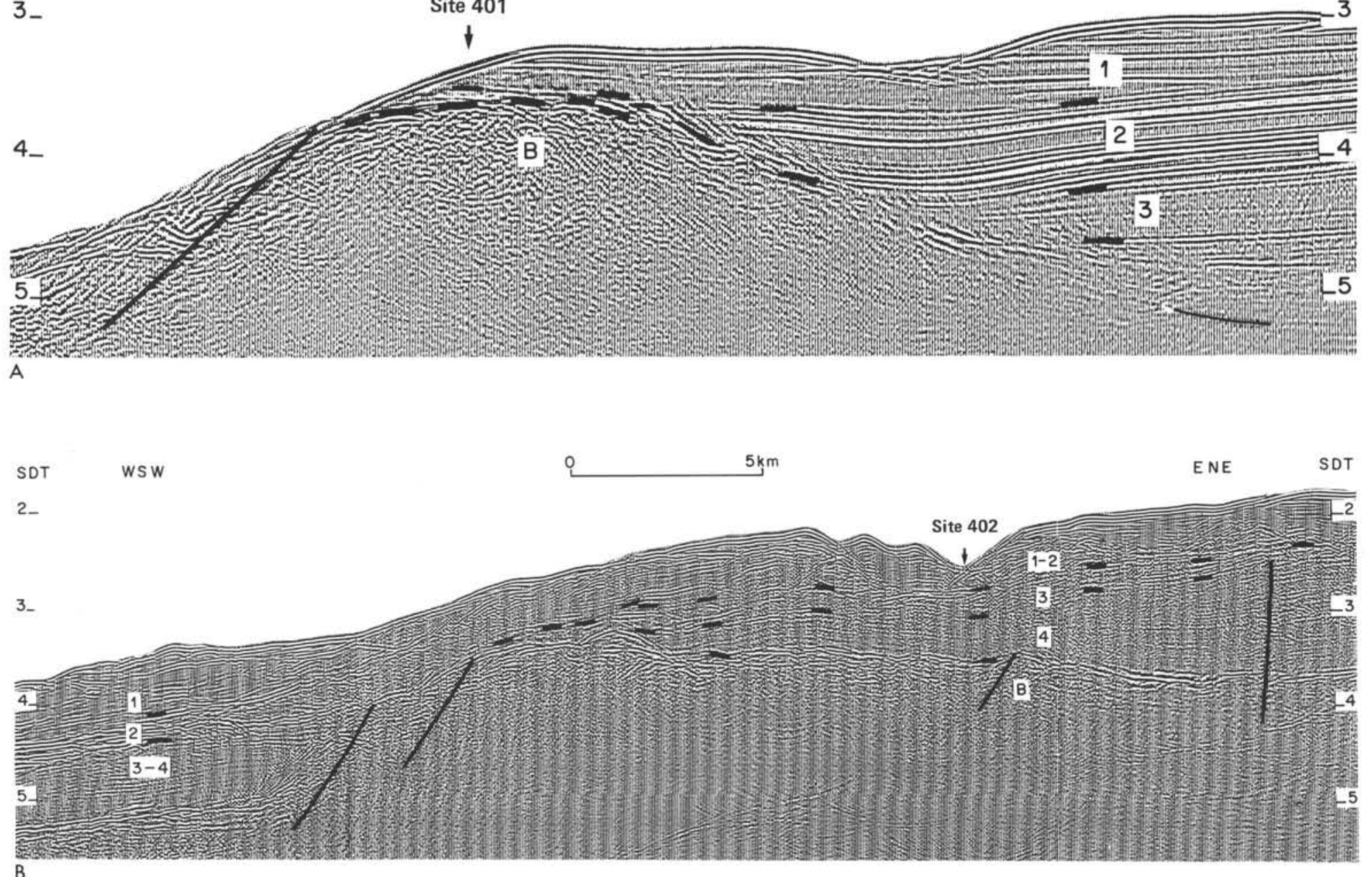
B

Figure 10. (A) Seismic profile through Meriadzek Escarpment and Site 401. Formation 1 is post-Eocene Cenozoic, Formation 2 Upper Cretaceous to Eocene, Formation 3 Aptian-Albian. Site 401 is on top of a tilted block the crest of which has been eroded during the preAptian-Lower Cretaceous rifting. Top of B is made of shallow water Upper Jurassic-lowermost Cretaceous carbonates covered by thin upper Aptian chalks and reduced Formations 1 and 2. Profile S21 migrated. (B) Seismic profile through upper slope and Site 402. Formations are the same as above. Note the tilted block with syn-rifting Formation 4. Formation 3 comprises the Aptian-Albian black shales deposited as a prograding shelf. Profile OC 301 migrated. 


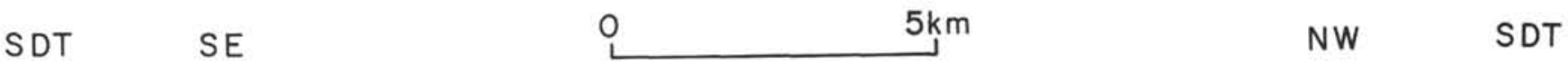

3

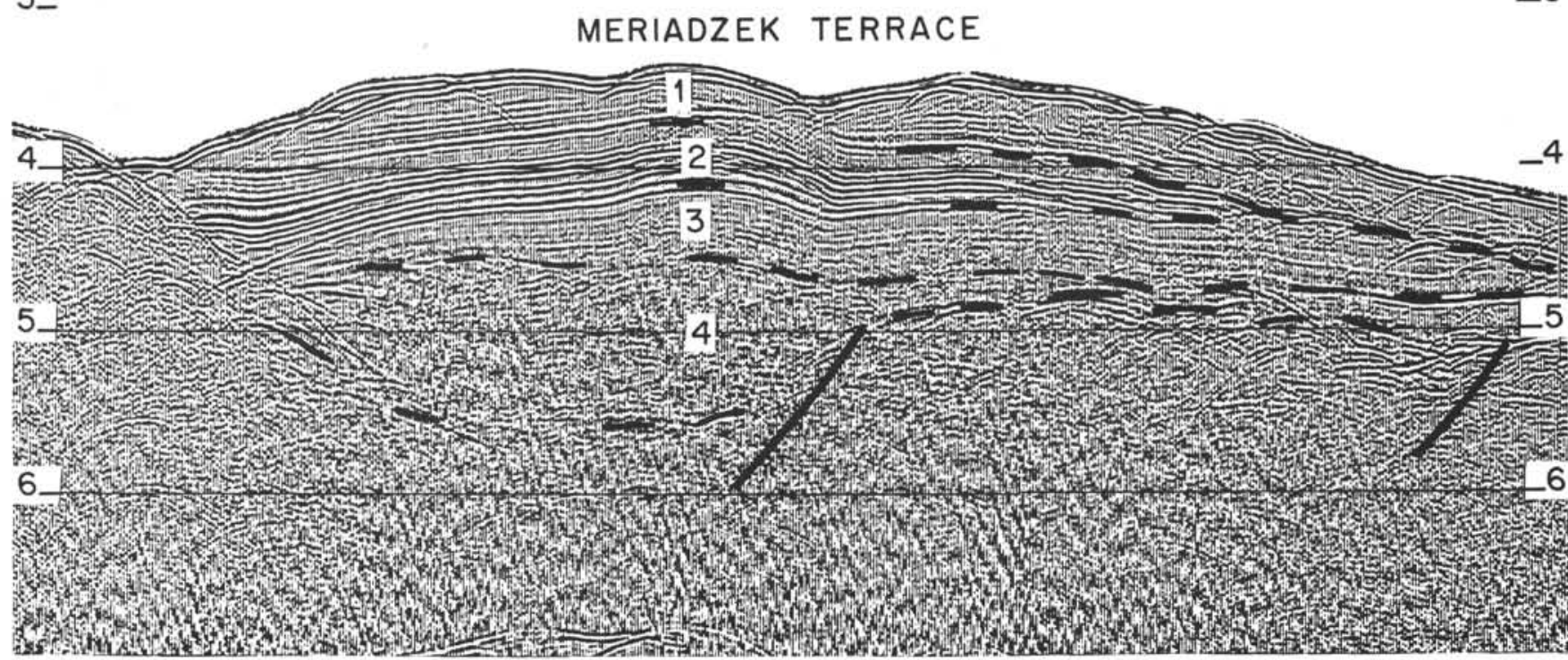

Figure 11. Seismic profile through the Meriadzek Terrace. Note the important erosional event between Formations 1 and 2 , of probably late Eocene-early Oligocene age. Formations 2 and 3 (Aptian-Albian) are completely eroded. To the left, note the erosion of Formation 3 along a basement high indicating that between Aptian-Albian and Late Cretaceous time, bottom currents were active.

divided into Formations 1 and 2 because a structural or erosional unconformity commonly occurs within the sequence. Its lower part, Formation 2, is distinguished easily from the overlying Formation 1 where the two are unconformable (Figures 8A, 8B, and 9), but, elsewhere, the units are identified only on the basis of layer-to-layer correlation. Generally Formation 2 contains more reflectors than Subunit $1 \mathrm{~b}$, except in areas of thick distal deposition (the abyssal plain), where it may be the contrary (Figure 9). It is to be noted that Formation 2 is layered in most areas. In those cases where post-rift deformation is observed, Formation 2 is always affected but not Sub-unit $1 \mathrm{~b}$. Off Galicia and Portugal (DSDP Leg 47), similar unconformities were observed at the boundary between Formations 2 and $\mathrm{Ib}$ as there defined.

The thickness of Formation 2 in north Biscay is between 400 and 800 meters, reaching its maximum beneath the abyssal plain. In Shamrock Canyon, it may be condensed into a single reflector, but in other areas, e.g., Meriadzek Terrace, it may be eroded completely.

\section{Formation 1}

Formation 1 is the youngest and is weakly layered. Beneath much of the north Biscay margin (except the upper part of the continental slope and the shelf) it can be divided into two members, $1 \mathrm{a}$ and $1 \mathrm{~b}$, the latter being more intensely layered. In high-resolution seismic profiles, a larger member of sub-units can be distinguished locally but their correlation throughout the area is difficult.

The lower member, as pointed out, is often unconformable on Formation 2, but may be conformable over large areas; Sub-unit 1a is almost everywhere conformable with Sub-unit $1 \mathrm{~b}$. The whole of Formation 1 is 600 to 900 meters thick, its thickness being greatest beneath the abyssal plain and the continental slope (1200 to $1400 \mathrm{~m}$ ). The formation is characterized by large-scale features. Thick accumulations occur on the sides or at the outlets of submarine canyons, e.g., on the southern flank of Shamrock Canyon (Figure 12A). At the foot of continental slope, sediment dunes or giant ripples are observed (Figures 12B and 12C). In the mouth of Shamrock Canyon, internal dips within dunes indicate an apparent bottom current component towards the south-southwest. This may be related to peculiar hydrodynamics in the canyon during Pleistocene and Recent times or to a polewards-directed, eastern boundary current identified by Swallow et al. (personal communication).

\section{Sound Velocity in the Formations}

Lithological interpretations can be made from estimates of compressional wave velocities in the sediments. In north Biscay, 400 velocities were calculated and were also used for the construction of depth sections. These velocity values were obtained by the Dix relation from "root mean square velocities" spectra after processing of seismic records (Figure 13). In Figure 14, mean formation velocities are shown as a function of mean formation depth (or mean formation two-way travel time) under the sea bottom. Two types of curves are apparent. In one group, the velocity/depth variation is positive and regular and ranges from about $2.0 \mathrm{~km} / \mathrm{s}$ in Formation 1 to $2.5 \mathrm{~km} / \mathrm{s}$ in Formation 2, and 3.0 to 3.5 $\mathrm{km} / \mathrm{s}$ in lower formations. In the second group, there is a similar increase in Formations 1 and 2 to a maximum 3.0 $\mathrm{km} / \mathrm{s}$ but the velocity decreases in Formation 3 by about 0.3 $\mathrm{km} / \mathrm{s}$ and increases again in Formation 4 and the basement. These results may be explained by the near absence of carbonates in Formation 3 due either to deposition close to the 


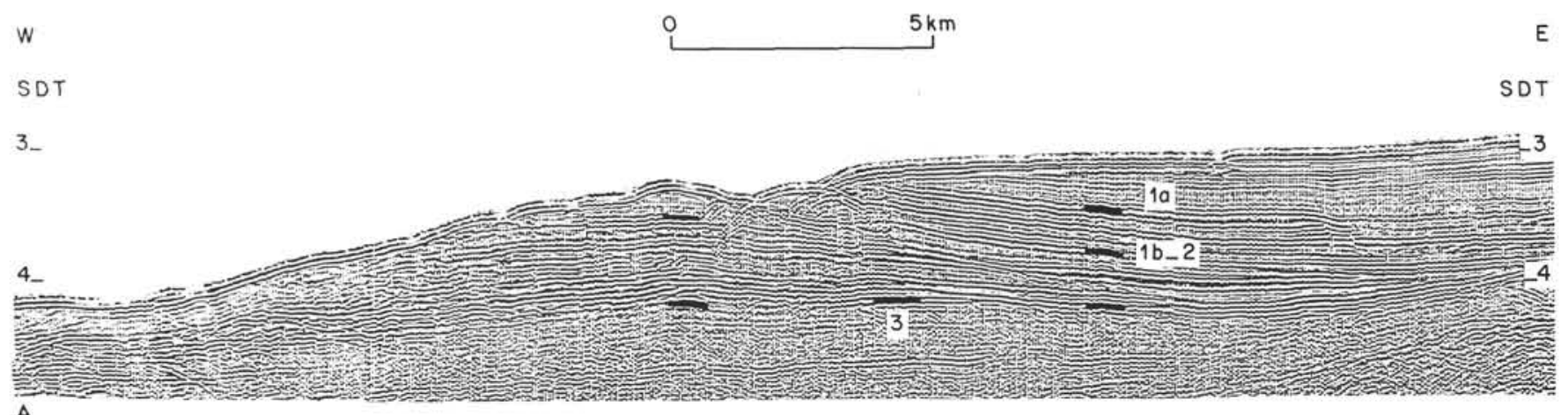

A

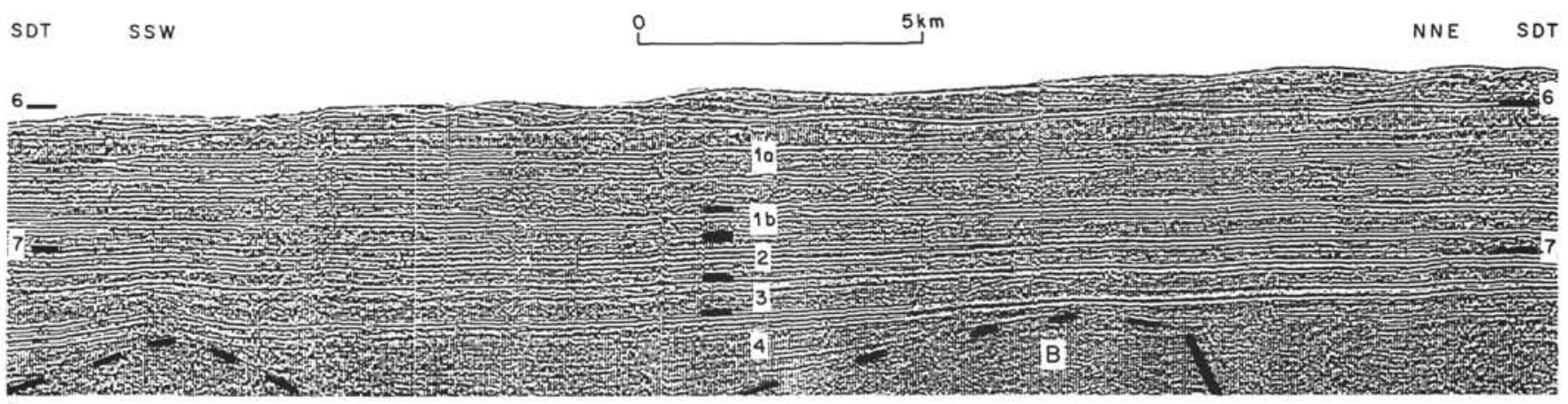

B

w

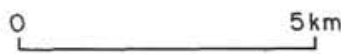

$E$

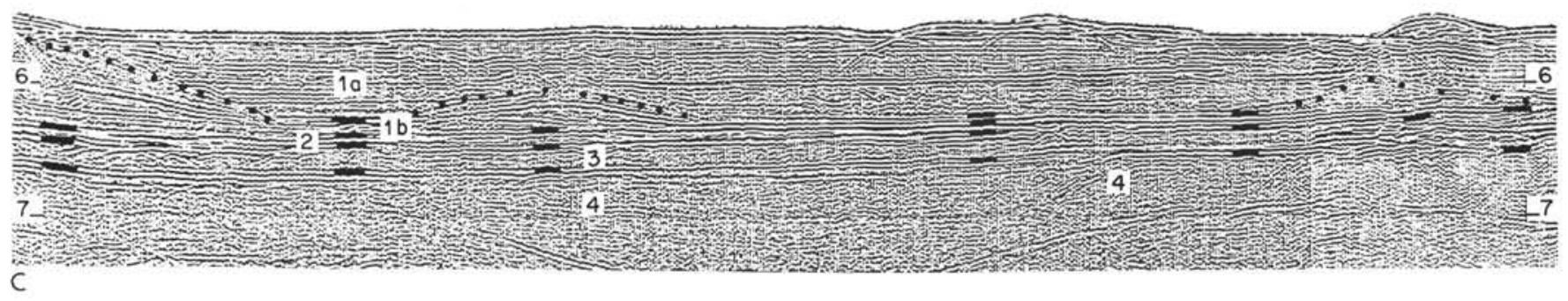

Figure 12. (A) Sedimentary fan on the left bank of Shamrock Canyon. The profile (OC 302, unprocessed) cuts the axis of the canyon on the left with an angle of about 30 degrees. (B) Dunes or megaripples at top of Formation 1a Profiles OC 308 at foot of continental slope, unprocessed. (C) Dunes or megaripples in Formation $1 b$. Formation 2 is condensed or eroded at this site. Profile OC 302 at foot of continental slope, unprocessed.

CCD or to the presence of abundant clays. However, there is no direct evidence for either assumption because of the paucity of lithologic data from Formation 3. In Hole 400A, only a slight velocity decrease (only 4 samples with Vp $>1.90 \mathrm{~km} / \mathrm{s}$ ) was observed, and the seismic data show no decrease (Figure 14, Profile OC 412). Site 401 was drilled through a condensed Lower Cretaceous section. At Site 402, drilled through 200 meters of Aptian sediments, sonic $\log$ velocities ranged between 2.0 and $2.5 \mathrm{~km} / \mathrm{s}$, close to the seismic measurements of $2.4 \mathrm{~km} / \mathrm{s}$ and lower than those in the Albian (both in hole and seismic data). Further seismic velocities observed in the Trevelyan area and in the canyon bottom (curves B in Figure 15) show a regular increase with depth.

The relation of sound velocity-burial depth and deposition is complex. Nevertheless, if velocity curves are classified according to the formation depths (Figure 15), it can be seen that there is no velocity decrease in the continental slope formations (present depth above $3 \mathrm{~km}$ ), whereas curves below $3 \mathrm{~km}$ often show a decrease at the level of 


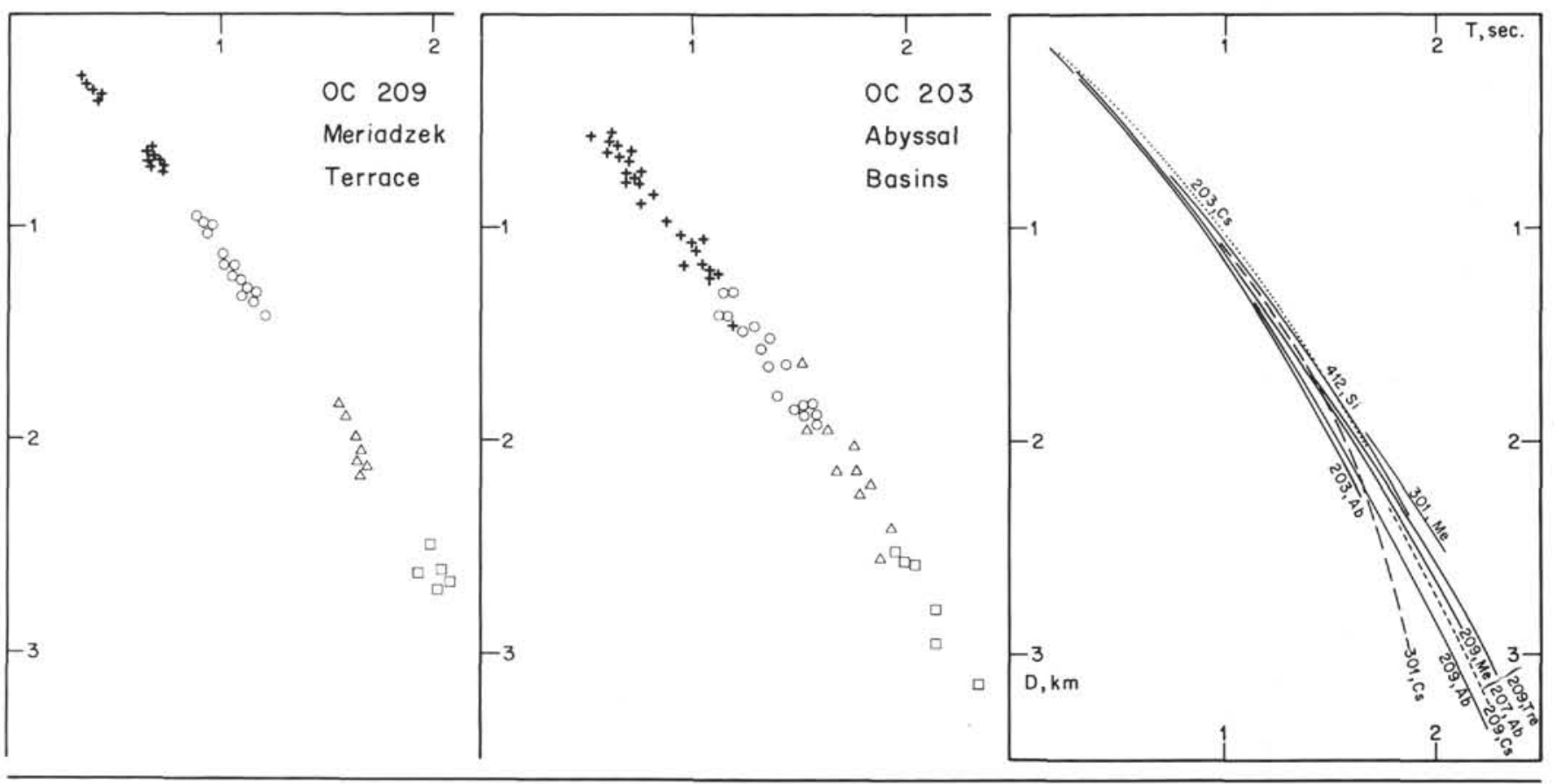

Figure 13. Sound velocity. Two-way travel time (horizontal scale, in s) versus calculated depths (vertical scales, in $\mathrm{km}$ ) mean curves. Curves on the right were obtained from time-depth plots such as those presented on the left and center of figure. Points corresponding to Formations 1, 2, 3, and 4 are represented on the plots, respectively, by crosses, circles, triangles, and squares. Curves drawn on transparencies were used for the construction of depth geological sections from seismic profiles. At a level corresponding to two s of time, there may be a difference of about 300 meters on depth between the "quickest" and the "slowest" curves. High velocities are especially evident on curves 209 and 301 CS (continental slope) where the deep seated sediments may be carbonates. Letters CS, Tre, Si, Me and Ab refer to parts of profiles located respectively on continental slope, Site 400, Trevelyan, Meriadzek, and the abyssal plain.

Formation 3, which would have been deposited close to the CCD. Lack of a comparable structure in the Trevelyan and Whithard areas may be due either to some inaccuracy in the method or to the presence of carbonates brought down below the CCD by turbidity currents. These results should be compared with those obtained in the west Iberian margin, where low velocities recorded in Formation 3 have been related to the low carbonate content of sediments in Hole 398B.

\section{Correlation of Formations With the Lithological Units of the Holes}

Detailed correlations between seismic units and major lithologic changes on the holes are discussed in the Site Chapters (this volume). In the present chapter a summary of these correlations is given, with a discussion of the validity of tracing some of the horizons far from the drill sites.

\section{Holes 400 and 400A (Figure 6)}

Formation 1a corresponds to Quaternary, Pliocene, and upper-middle Miocene oozes and chalk. Formation $1 \mathrm{~b}$ is the underlying layered sequence, the base of which is the Oligocene/middle Eocene hiatus. The sequence is composed of an upper slightly layered member and a lower more strongly stratified member and corresponds to lower Miocene, Oligocene oozes, nannofossil chalks, and marly chalks with mudstone layers. Although well defined in the Site 400 area, this sequence is not easily correlated far from the hole, because it is very similar in appearance to Formation 2 and the boundary between the two formations may be not clear where the formations are conformable. In some cases, Formations $1 \mathrm{~b}$ and 2 have not been distinguished.

Formation 2 corresponds in the hole to the sequence defined at the top by the Oligocene/middle Eocene hiatus and its base by the Upper/Lower Cretaceous hiatus. The sequence is composed of alternating marly chalks and mudstones.

Formation 3 was drilled in part and is composed of carbonaceous mudstones, marly chalks and limy claystones of Albian to Aptian age. This sequence is correlated with all the transparent or slightly layered sequences underlying Formation 2 observed on the profiles at depths below two and one-half $\mathrm{s}$ beneath sea level. In many places, these layers are characterized by low interval velocity although this is not the case at Site 400 .

Formation 4 was not reached and is assumed to be of pre-Aptian Early Cretaceous age.

\section{Site 401 (Figure 10A)}

Formation 1 was partly drilled at Site 401 and corresponds with the Quaternary to Oligocene sequence. The top of Formation 2 has been correlated with the late Eocene unconformity (Reflector 1 in the hole) that is clearly seen in the right part of the profile in Figure 10A. Formation 2 is composed of siliceous nannofossil chalk and marly nannofossil chalk of middle Eocene to Late Cretaceous age. 

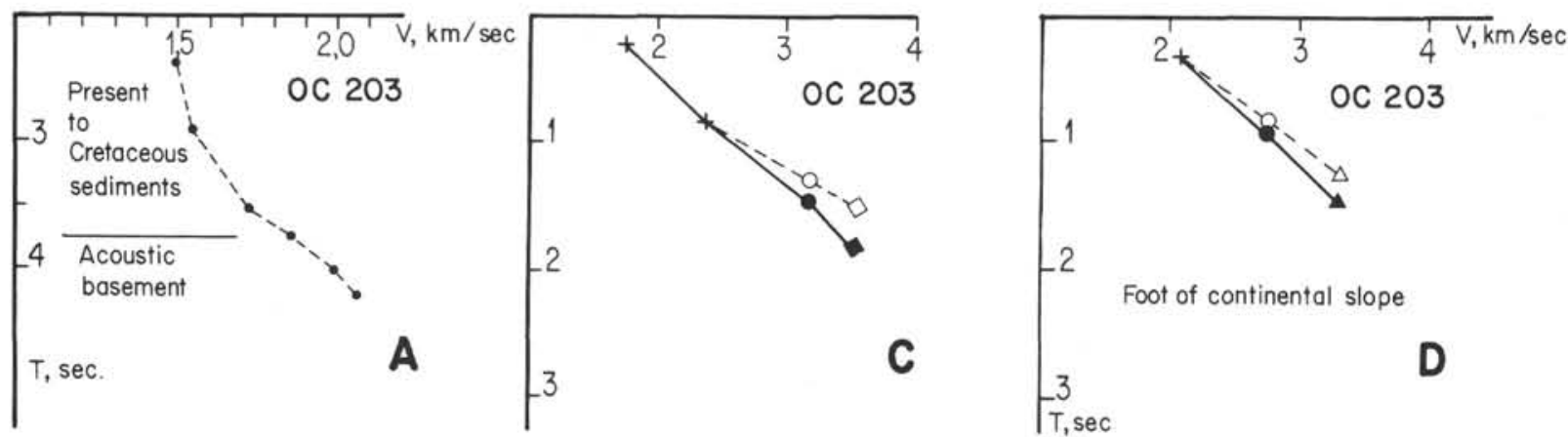

$\mathrm{D}, \mathrm{km}$
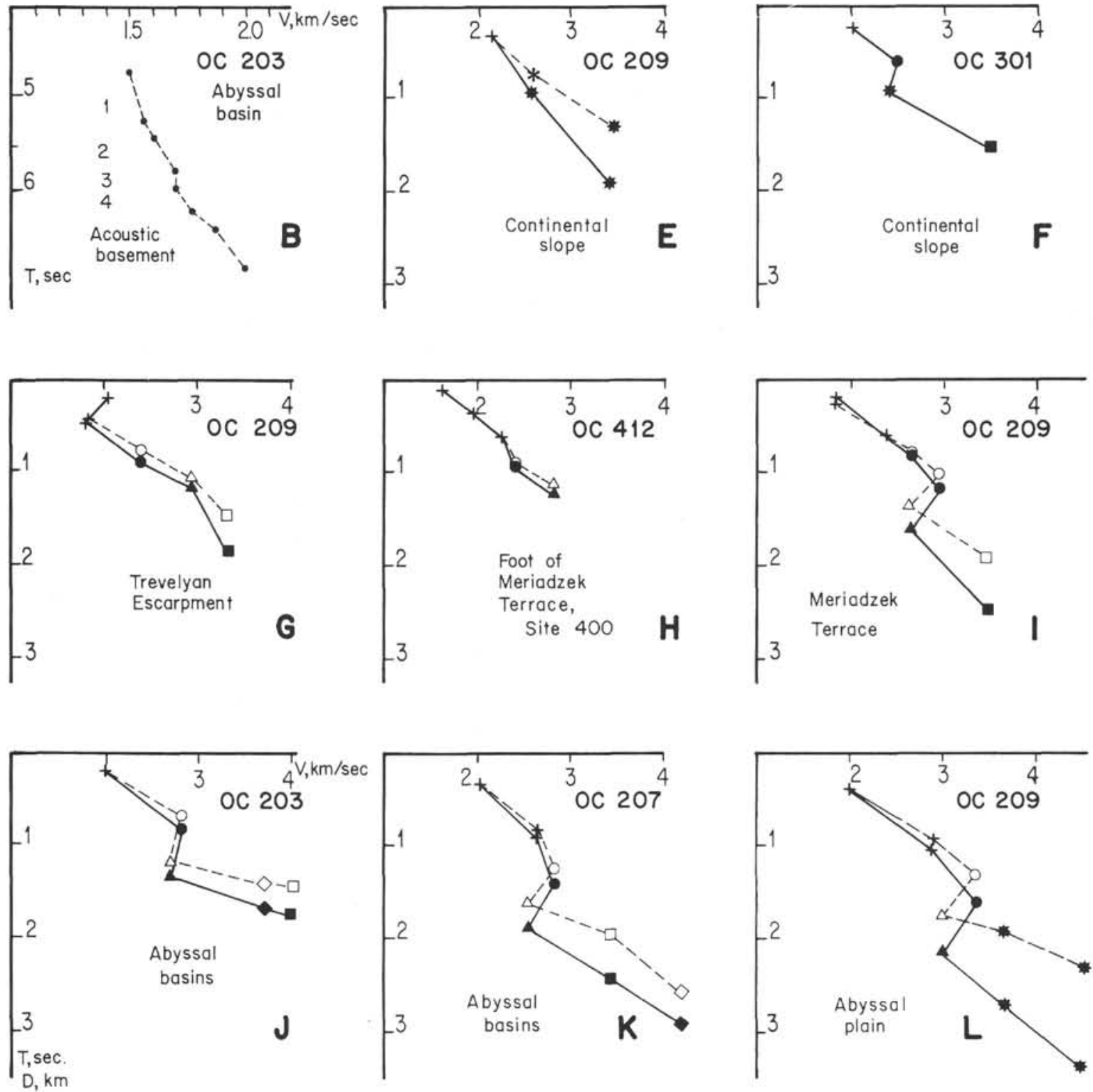

Figure 14. Relation between interval sound velocity and depth below sea bottom. Graphs $A$ and B: relation between mean velocity ( $\mathrm{rms}$ velocity, $\mathrm{km} / \mathrm{s}$ ) and two-way travel time below sea level ( $\mathrm{s}$ ) as obtained from velocity analyses. Graphs $C$ to $L=$ velocities $(\mathrm{km} / \mathrm{s})$ and two-way travel time below sea bottom $(\mathrm{s})$ and depth below sea bottom $(\mathrm{km})$. Horizontal scale $=$ velocities. Empty figures and dashed lines $=$ velocity versus travel time. Black figures and solid lines $=$ velocity versus calculated depth. Crosses $=$ Formation 1; circles $=$ Formation 2, triangles $=$ Formation 3; squares Formation 4; lozenges $=$ acoustical basement $;$ stars $=$ uncorrelated sediments. 


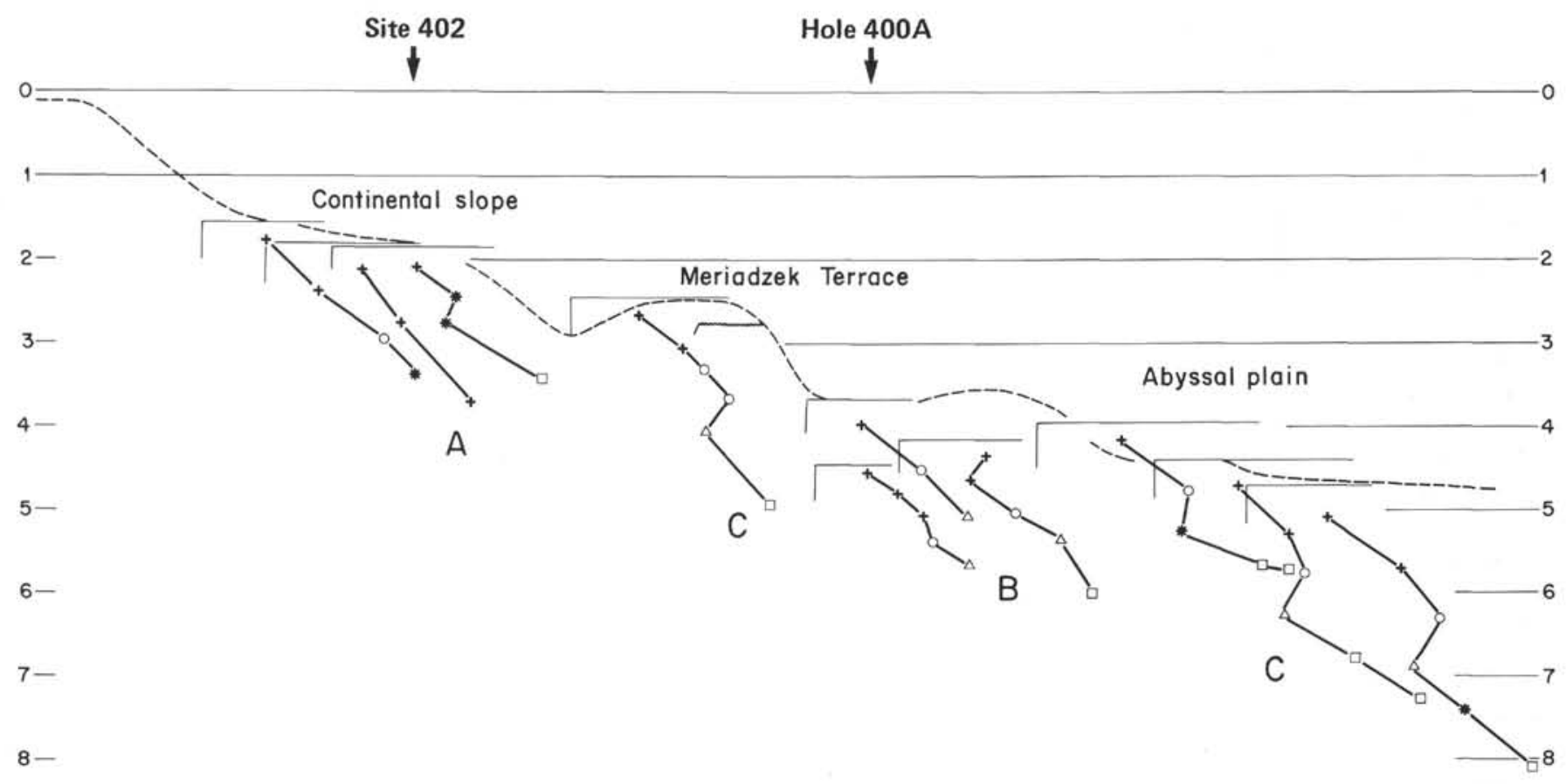

Figure 15. Sound velocities of formation may be influenced by their situation in the margin and depth below sea level. The sound velocity curves of Figure 14 are placed here at the approximate situation of sampling on the margin; the depth of formations (vertical scale, in $\mathrm{km}$ ) is the present depth. Increase of sound velocity with burial is regular in continental slope sediments; in sediments deeper than $3 \mathrm{~km}$ below sea surface, of Meriadzek and the abyssal plain (C), there is a decrease of velocity at the level of Formation 3 (triangles). Some curves corresponding to formations at the foot of continental slope or Trevelyan escarpment do not follow this rule (B).

Formation 3 is not visible on the profiles near Site 401 , where thin upper Aptian chalks were drilled. It is well developed to the north of the site where it is characterized, as elsewhere, by weak layering and low sound velocity. The acoustic basement drilled at Site 401 consists of Upper Jurassic to possible lowermost Cretaceous shelf bioclastic limestones.

\section{Site 402 (Figure 10B)}

In the deep part of Profile OC 301, the sequence resembles the succession from Formations 1 to 3 , the lower being a low sound velocity formation. In the upper part of the profile through Site 402 , there is also a sequence consisting of an upper, almost transparent, formation, a layered middle formation, and a lower transparent one. Data from Site 402 reveal that the upper formation consists of Quaternary muds and oozes with ice-rafted pebbles and late Eocene nannofossil and foraminiferal ooze. The Neogene section is much reduced. The layered sequence comprises middle Eocene siliceous nannofossil chalks and limestones, above a series of carbonaceous calcareous mudstones, and limestones of Albian and Aptian age. The almost transparent lower formation has not been drilled, but must represent pre-Aptian Lower Cretaceous sediments contemporaneous with the rifting. A part of the layered formation is therefore of Early Cretaceous age and corresponds to Formation 3 as defined elsewhere. The lower sequence must be correlated with Formation 4 .

The stratigraphic controls provided by dredging (Auffret et al., this volume) will be discussed later, but generally support the seismic interpretation.

\section{The Main Unconformities}

Several unconformities are observed on the north Biscay continental margin. Some are related to structural movements, others to paleoceanographic events. The lowest unconformity of structural origin separates the post-rifting sediments from the underlying sediments which were affected by rift tectonics. Because the paleotopography created by rifting was very pronounced (Figure 4) and the post-rift sediments are very thin, every instance from no visible unconformity in a half graben to non-deposition of sediments of post-Aptian age on the crest of a tilted block is present; fault block crests even outcrop on the sea bottom. However, beneath large parts of the margin, the change in regime from rifting to subsidence occurred in deep waters so that deep syn-rift sediments grade, without interruption, to deep post-rift sediments in half grabens. In these cases, one cannot observe a "continuous break-up" unconformity.

Another unconformity of structural origin is observed locally in areas which were affected by late Eocene compressional movements. This is particularly clear along the Trevelyan escarpment which largely was created at that time.

Another unconformity separates the Upper Cretaceous chalks from the Aptian/Albian "black shales." A large hiatus of Cenomanian to Santonian age separates the two formations in north Biscay. The unconformity is emphasized by the change of seismic facies between the transparent Formation 3 and the strongly layered Formation 2. Angular truncation of the black shales below Formation 2 at the unconformity (Figures $8 \mathrm{~B}, 11$ ) is due to differential 
compaction of the black shales in the half graben during a period of non-deposition and bottom current activity. This hiatus is known in many parts of the Atlantic and is due to a major paleoceanographic event synchronous with the global Cenomanian-Turonian transgression, whose origin is not yet well understood.

Between Formation 2 (Upper Cretaceous to late Eocene) and Formation 1, an unconformity is also often visible and associated with strong erosion (Figures 10A, 11). This event, which occurred between the late Eocene and Oligocene, has not been dated with great precision, but it clearly post-dates the middle Eocene paleoceanographic change that is marked by a sharp increase of silica production. This paleoceanographic event is linked to the onset of a strong bottom water circulation that caused erosion, sediment drift, dunes, and sediment waves, resulting in a seismic facies markedly different from Formation 2 which contrasts mainly in being characterized by pelagic draping. This event probably affected the whole Atlantic and could be synchronous of the "great sculptural event" described on the western Atlantic margin (Tucholke and Mountain, 1978).

Formation 1 is also composed of different depositional sequences separated by unconformities that are particularly visible on the upper slope, and possibly related to eustatic changes in sea level (Figure 16). They are, however, difficult to pick over the entire margin.

\section{THE STRUCTURAL EVOLUTION OF THE CONTINENTAL MARGIN}

\section{The Rifting Phase \\ Pre-Rifting Geology and Beginning of Rifting}

Seismic reflection profiles show that the fault blocks (Figures 4,6 ) contain either thick-layered sediments, the parallel inclined reflectors of which are clearly seen in front of the Western Approaches Basin, or basement with a thin sedimentary cover in the area of Goban Spur. Data on the age and nature of these rocks are rather scarce. At Site 401, on Meriadzek Terrace, Upper Jurassic and possibly lowest Cretaceous calcarenites were penetrated below a horizontal erosional surface. These sediments may represent a pre-rift carbonate platform. Upper Jurassic calpionellid limestones dredged on the Meriadzek Terrace (Pastouret and Auffret, 1976) support this interpretation, but they also indicate more open sea conditions. Since the exact age for beginning of the rifting phase is not known, an alternative hypothesis is that the Upper Jurassic shallow water carbonates found at Site 401 are geographically restricted to the highest point of previously faulted blocks. Several dredges in the Goban Spur area (Granite Cliff, Menez Bihan, Figure 2) recovered granitoides, ages of which vary from 251 m.y. to 290 m.y., indicating a Hercynian basement. Metamorphic rocks and sandstones and shallow water carbonates of probable Carboniferous age have also been dredged (Auffret et al., this volume). These lithologic data confirm the seismic reflection data, and demonstrate the existence of two geological provinces prior to rifting, one with thick Mesozoic deposits in front of the Western Approaches Basin, and another on Goban Spur that corresponds to a regional basement high with a thin Mesozoic sedimentary cover. These geological realms are known on the shelf as the Western Approaches Mesozoic Basin and the basement high running from Cornwall to Goban Spur and are intersected by the present margin and the initial rift. In the margin of north Biscay, rifting therefore occurred in a pre-existing marine Mesozoic basin, in contrast to many rifts which developed on an ancient subaerial basement.

The pre-rift paleogeography is still disputable because of the lack of deep stratigraphic data on the margins and uncertainties on the pre-rift reconstructions of Biscay. The Hercynian basement was subjected to a first phase of tensional tectonics during Triassic-early Liassic time with evaporite deposition that is well known in Aquitaine and part of Galicia-Portugal (Winnock, 1971; Rosset and Dardel, 1971; Montadert et al., 1971, 1974; BRGM et al., 1974). The Western Approaches Basin could also have been initially structured by this distension. It is noteworthy that, in the Aquitaine, the northern boundary of the thick Triassic deposits is a fault system (the Celtaquitaine flexure of Winnock, 1971) which is exactly in the prolongation of the present Armorican continental margin. The tensional movements ceased in Aquitaine in the Jurassic when marine epicontinental sediments were deposited indicating an open sea toward the west. The bathymetry of this Mesozoic sea is not well established offshore, but calpionellid limestones are known all around Biscay. In northern Biscay, seismic reflection profiles consistently show a downslope facies variation of the pre-rift Mesozoic, with the developments of a well-layered series perhaps indicating more basinal deposits. This change is exemplified by Figure 10 upslope and by Figure 6 downslope.

After the quiet period at the end of the Jurassic, tensional tectonism occurred again throughout the Europe/America plate, creating a complex system of rifts. Some of these subsequently aborted, as in the North Sea or in the Western Approaches, but others evolved to form a passive continental margin with accretion of new oceanic crust.

In northern Biscay, the start of this rift episode is not well documented. In the Western Approaches Basin, results of exploratory wells have not been published, but in the Celtic Sea, the break-up unconformity is of Aptian age. In Aquitaine, it is particularly well documented for the Parentis Basin which opens directly westward into Biscay. Detailed maps based on drilling results (BRGM et al., 1974) indicate that the Parentis Basin is first identifiable in upper Oxfordian as an area of slightly more rapid subsidence. During the Neocomian, the Parentis Basin became a large graben, indicating a period of active rifting. Since the northern boundary of the Parentis Basin is in continuity with the Armorican margin, the timing may be extrapolated to the northern Biscay and is not in contradiction with our observations.

It is thus concluded that in northern Biscay, active rifting took place in Early Cretaceous time in a pre-existing marine basin in contrast to many rift systems described in the literature as having been subaerial.

\section{The Tectonic Style of the Rift System}

The tectonic style of rifting is exemplified by several interpretative depth sections across the margin, based on seismic reflection profiles (Figures 2, 3, 4). Profiles OC 


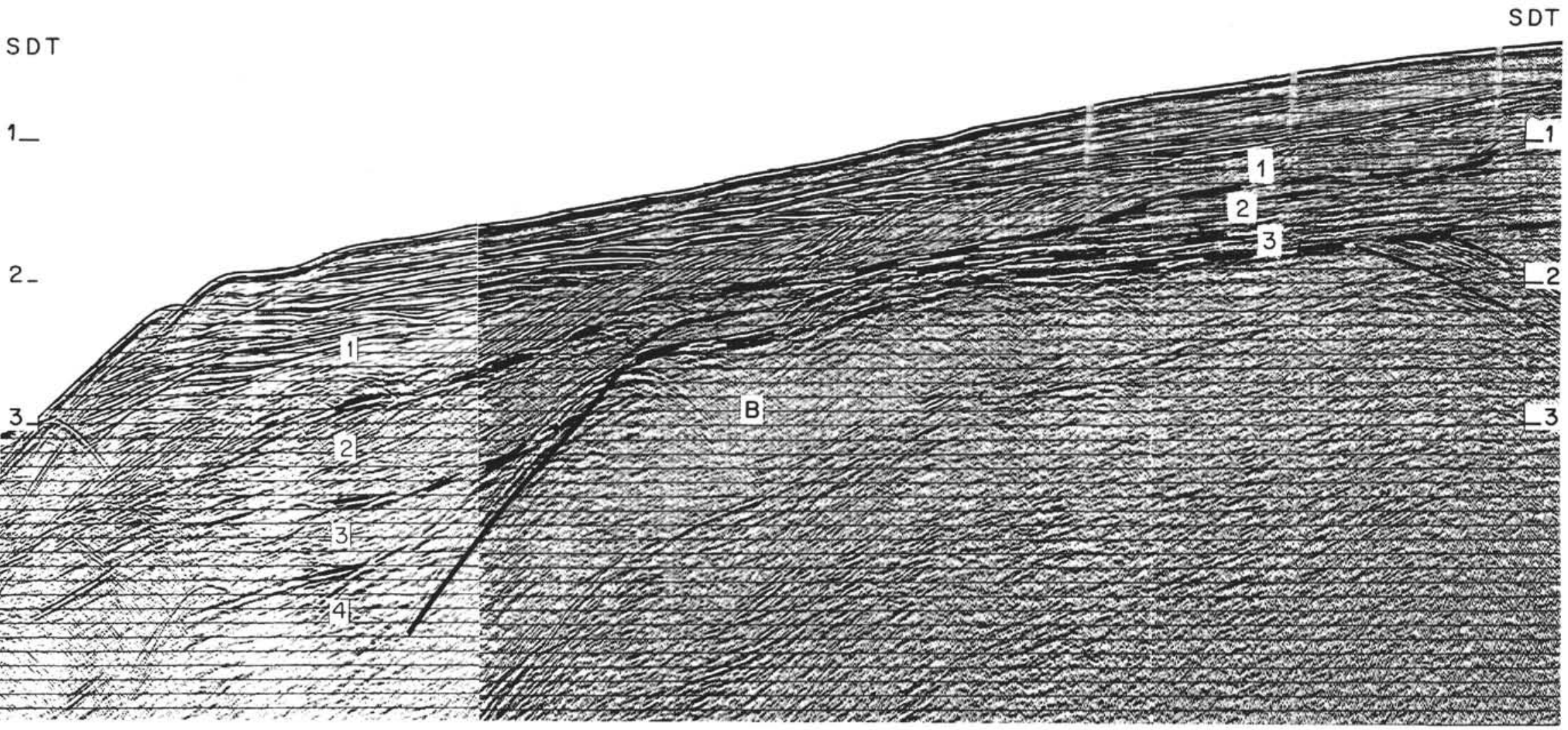

Figure 16. Lower Cretaceous erosional surface near the shelf edge. Upper continental slope. Unit 1 comprises at least three depositional sequences. Formations 2 and 3 vary considerably from left to right on top of a tilted block eroded during Early Cretaceous rifting. Formation 2 thins considerably whereas Formation 3 , of Aptian/Albian age, probably rests directly on top of the erosional surface. Profile CM 14, processed. 
209 , OC 207, OC 205 are typical of the area in front of the Western Approaches Basin, whereas Profiles OC 203 and OC 202 lie, respectively, south of and upon the Goban Spur. The overall tectonic style is characterized by a series of tilted blocks bounded by faults which, in many cases, are clearly listric or panamean faults. These blocks delineate half grabens. True horsts are rare.

Some of these blocks are cut by erosional surfaces, which on too highly exaggerated profiles give the misleading appearance of horsts. There is a clear polarity of the dip of faults towards the axis of the rift system.

A schematic fault pattern of the rift system developed in this part of Biscay during Early Cretaceous has been mapped from the seismic profiles (Figure 17). The pattern is best documented in the area of Meriadzek where the spacing of the profiles is less than $10 \mathrm{~km}$. However, delineation of fault trends there is often uncertain and more so in the area of Goban Spur.

Spacing between consecutive fault block crests varies from a few kilometers to $30 \mathrm{~km}$ and the length of individual blocks is limited to between several and 20 to $30 \mathrm{~km}$ by transecting normal faults that do not show horizontal displacement. These faults are often delineated by the lack of continuity of tilted blocks. The apparent throw varies along the faults because crests and half grabens do not coincide on both sides. Comparable patterns have been described on intracontinental rift systems such as the southern Ethiopian rift system (Moore and Davidson, 1978).

The trend of the tilted blocks generally follows the strike of the margin and changes between the Goban Spur $\left(150^{\circ} \mathrm{E}\right)$

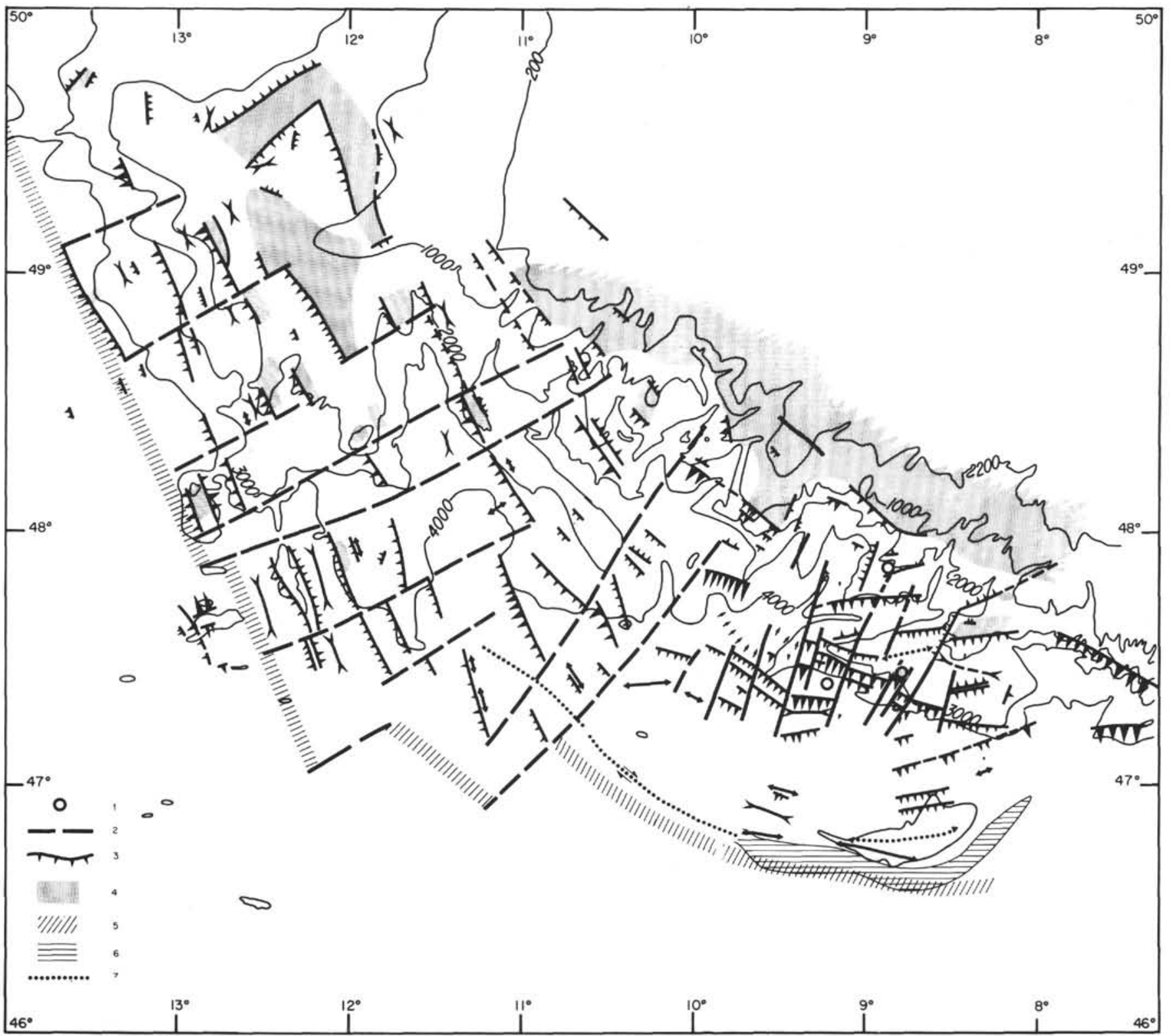

Figure 17. Schematic tectonic patterm of the rift system in northeast Biscay. $1=$ Sites $400,401,402 ; 2=$ Faults; $3=$ Listric faults with arrows down dip; $4=$ Pre-Aptian erosional surfaces; $5=$ Continental $/$ oceanic crusts boundary; $6=$ Tectonized area along Trevelyan escarpment due to late Eocene compression; $7=$ Late Eocene strike-slip fault or folds. 
and the Meriadzek area to more variable trends of $80^{\circ}$ to $130^{\circ} \mathrm{E}$. Transecting faults oriented almost perpendicular to the margin vary in direction from $60^{\circ} \mathrm{E}$ in Goban Spur area to $15^{\circ}$ to $30^{\circ} \mathrm{E}$ in the Meriadzek area where trends are again more variable. If, as is probable, faulting during rifting accommodated previous fractures or inhomogeneities in the Hercynian basement, the observed differences in fault orientation suggests that the Hercynian basement in the areas of Goban Spur and Meriadzek is different on both lithology and structure. In any case, the faults trending at $80^{\circ} \mathrm{E}$ in the Meriadzek area, and controlling in particular the Shamrock Canyon, have clearly the same orientation as the Hercynian shear zones of Brittany (Figures 1 and 4).

Of particular interest and significance for the rifting process is the nature of listric faults created during rotation of the blocks. The base of the syn-rifting sediments is a datum which allows determination of the throw of the faults. For listric faults, this throw is a function of the amount of rotation of the block and the width of the block. It may be as much as 3 to $4 \mathrm{~km}$ for some large individual blocks. Tilting of the blocks involves their rotation about axes parallel to their strike. Depth reconstruction from seismic profiles (Figure 4) shows that rotation of the block is commonly $20^{\circ}$ to $30^{\circ}$. The change of dip of the faults with depth which characterizes listric faults is especially visible beneath the rise, where the faults become near horizontal with depth below the blocks. Figure 6 shows details of individual block with listric faults and Figure 18 is a depth reconstruction of the same profile with the same horizontal and vertical scales. Such listric faults have been also described by Blair (1975) and Bowen (1975) in the North Sea and postulated by Lowell and Genik (1972) and Lowell et al. (1975) in the Red Sea and by Garfunkel and Bartov (1977) in the Suez Rift.
A reflector, often very strong, underlying the base of the listric faults is seen beneath the rise (Figure 19). Variations in travel time to this reflector are visible and shown as a "pull up" below the crest of the blocks, due to the velocity difference between beds within the blocks and sediments infilling the adjacent half grabens. It may therefore be assumed that this reflector is relatively flat and independent of the tectonized layer above. The same feature (Figure 20) observed at the foot of the western escarpment of the Galicia Bank area (Figure 1) demonstrates that it is not of local origin. Such a strong reflector must correspond to a sharp contrast in acoustic impedance and should therefore correspond also to a refraction horizon. On the north Biscay margin, refraction Profile D12 of Ewing and Ewing (1959) is unfortunately located at the western end of Trevelyan (Figure 2) on both continental and oceanic crusts, thus making the results of little value in this respect. However, a recent profile (no. 10) shot by CNEXO with OBS parallel to the foot of the Meriadzek escarpment (Figure 2) (Avedick et al., this volume) crosses the reflection profile shown in Figure 18. Below sediments with $2.1,3.1$, and $3.6 \mathrm{~km} / \mathrm{s}$ velocities, there is a $2-\mathrm{km}$-thick layer of $4.9 \mathrm{~km} / \mathrm{s}$ velocity whose base is situated nearly $9500 \mathrm{~km}$ below sea level, almost exactly at the level where the listric faults become nearly horizontal. Below, there is a 3-km-thick layer with $6.3 \mathrm{~km} / \mathrm{s}$ velocity above the Moho discontinuity $(8.2$ $\mathrm{km} / \mathrm{s}$ ) situated at $12 \mathrm{~km}$ below sea level. Computation of the interface between 4.9 and $6.3 \mathrm{~km} / \mathrm{s}$ layers would lie at $9.2 \mathrm{~s}$ two-way travel time, in good agreement with the observed travel time of the horizontal reflector below the tilted blocks. However, in view of the probable existence of horizontal inhomogeneities in the tectonized upper crust and the small thickness $(3 \mathrm{~km})$ of the $6.3 \mathrm{~km} / \mathrm{s}$ layer above the Moho, it is possible that the strong reflector below the tilted blocks could

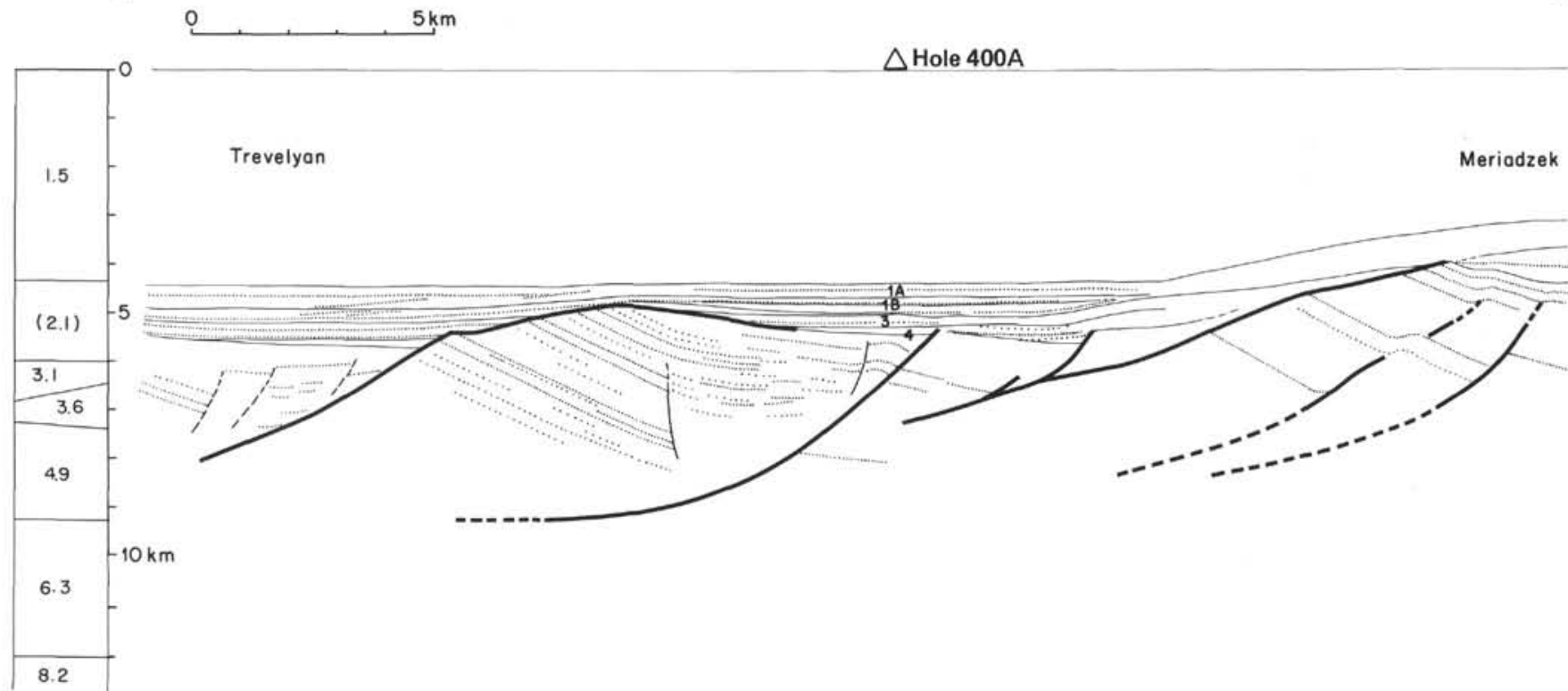

Figure 18. Geological cross-section through Site 400 with same horizontal and vertical scale, constructed from seismic reflection - Profile OC 412 migrated (see Figure 6). Note the listric faults bounding the tilted blocks. Near base of listric faults is a horizontal reflector corresponding to interface between $4.9 \mathrm{~km} / \mathrm{s}$ and $6.3 \mathrm{~km} / \mathrm{s}$ layers defined by seismic refraction data. Moho discontinuity is at $12 \mathrm{~km}$. 


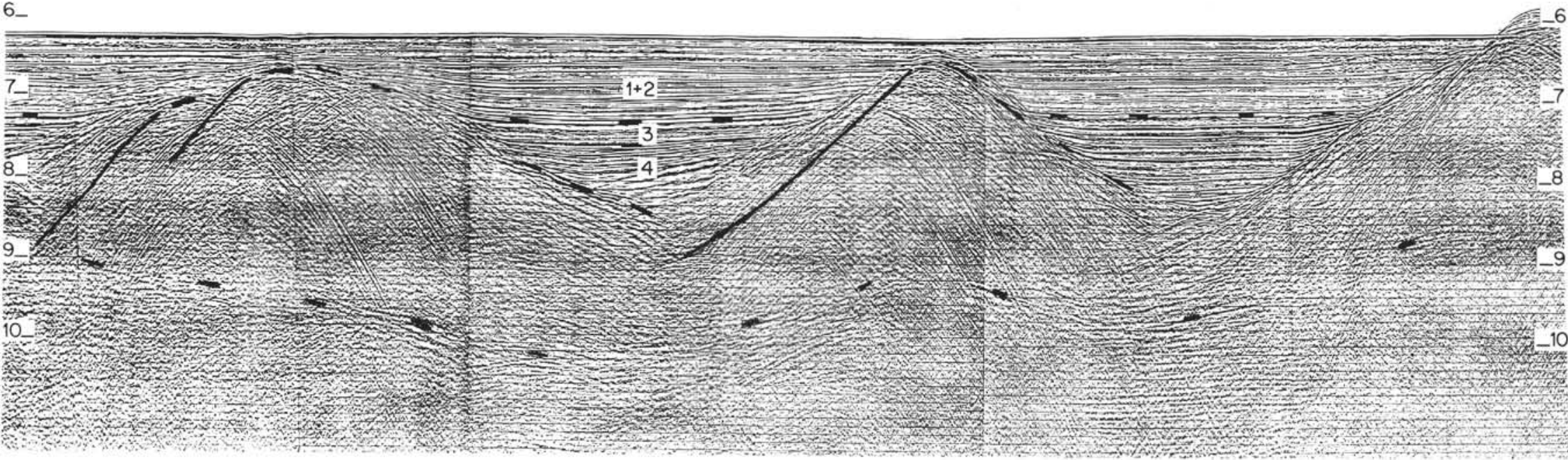

Figure 19. Seismic profile south of Goban Spur showing tilted blocks with listric faults. Note the horizontal reflector below the tilted blocks. It is observed on the deepest part of the margin. On Trevelyan it corresponds to the boundary between a $4.9 \mathrm{~km} / \mathrm{s}$ layer and a $6.3 \mathrm{~km} / \mathrm{s}$ layer only $3 \mathrm{~km}$ thick. The Moho is about $12.5 \mathrm{~km}$ below sea level. Profile CM 16, processed.

\section{SDT W}

6

$5 \mathrm{~km}$

6

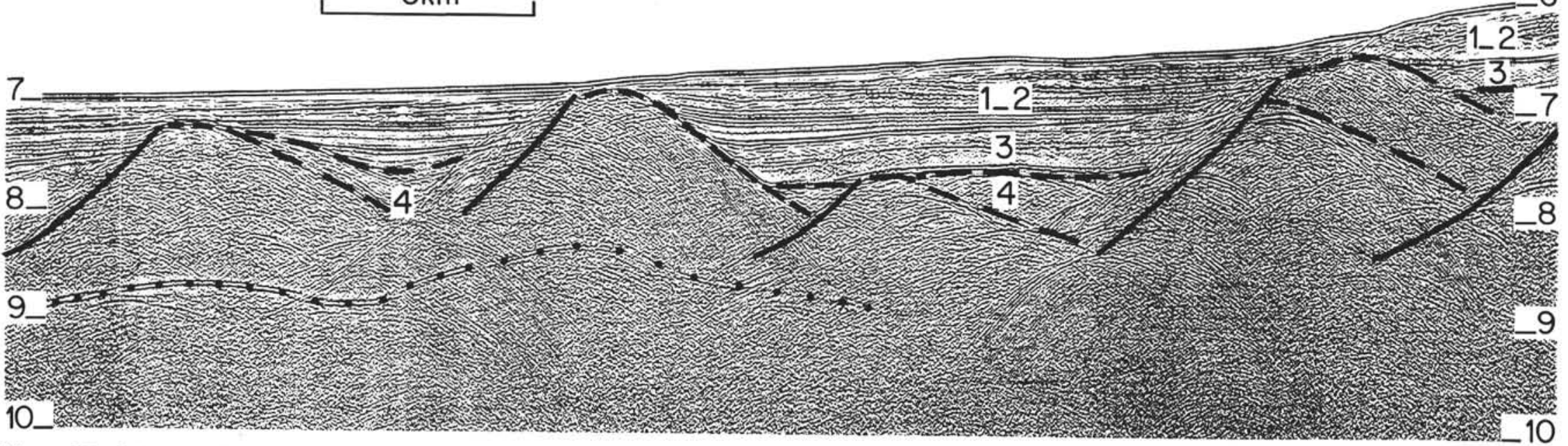

Figure 20. Seismic reflection profile immediately west of Galicia Bank showing tilted blocks and listric faults and a horizontal reflector below as on Figure 18 seismic Formations 1 to 4 are the same as defined in northern Biscay. Profile IFP-CNEXO-CEPM GP, processed. 
be the Moho discontinuity. More detailed seismic studies are clearly necessary. Drill and dredge data show that some tilted blocks include Mesozoic sediments, others Hercynian basement, demonstrating that the tectonized layer includes continental basement as well as sedimentary rocks. The geological and refraction data thus show that the boundary defined by the near horizontal base of the listric faults and the reflector does not correspond to a particular geological horizon in sedimentary rocks allowing decollement, but merely to a mechanical discontinuity within the upper part of the continental crust. This discontinuity, which clearly existed at the time of rifting, was situated at around 6 to $8 \mathrm{~km}$ below sea level in the central part of the rift south of Meriadzek as calculated from the depth section (Figure 18).

\section{The Syn-Rifting Sediments}

Sediments deposited during rifting (Formation 4) are generally well characterized by convergence of the reflectors towards the crest of the block indicating contemporaneous deposition during tilting (Figure 7). Due to the complex fault block pattern, the distribution of the syn-rifting sediments is complex and they may be thin or absent on top of the blocks, and thick in the half grabens behind large tilted blocks. In Figure 21 schematic isopaches of these sediments have been drawn on the rift pattern in the area of Meriadzek. Some troughs containing at least $2 \mathrm{~s}$ of section are present. The syn-rift section also thickens southeast of Trevelyan, marking the edge of the thick Amorican marginal basin, where the syn-rift sediments may well include a thick section of Aptian/Albian. As discussed in the Acoustic Stratigraphy section, the syn-rifting sediments are defined by not only the shape of the reflectors indicating syn-tectonic deposition, but also by their position below the well defined Formation 3 of Aptian/Albian age considered to be post-rift sediments.

In some grabens, the upper part of the syn-rifting sediments does not show any evidence of tectonic influence on their deposition and seems only to infill a pre-existing depression. This may indicate that rotation of the blocks stopped at different periods in different areas although the latest activity was probably intra-Aptian. In many cases, however, it seems more probable that the change from inclined syn-rifting sediments to horizontal pre-Aptian sediments is linked to a change in the tectonic regime from a half graben to a graben bounded on both sides by active faults. This fact, and the facies change observed in the Aptian-Albian in the abyssal plain, complicate the formation identification in areas like the Armorican marginal basin, where thick, almost continuous, sections of Albian/Aptian and pre-Aptian turbidites exist.

No precise stratigraphic data are available because Leg 48 drilling was not able to penetrate below the Aptian in a half-graben. Some dredgings (Auffret et al., this volume) found Barremian micritic limestones or marly chalks deposited at shelf or outer shelf depths in the Shamrock Canyon, and Valanginian to Barremian shallow water limestones or chalks on the Meriadzek escarpment. Drilling through a half-graben would be necessary to reconstruct the development and topography of the rift system.

\section{The Submarine Topography at the End of Rifting}

The Leg 48 drillings allowed correlation of seismic Formation 3 with the Aptian/Albian "black shales." On the seismic profiles this formation is not affected by rift tectonics but, near Site 402 (see Site Chapter), the lower Aptian nannoconid-bearing limestones are faulted whereas the top Albian is not affected. It is, therefore, concluded that rifting in this area most probably ended during Aptian time. This interpretation is supported by the presence of Formation 3 over the oceanic crust adjacent to the Trevelyan area (Figure 22) which demonstrates that the onset of spreading was close to Aptian time.

The drill and dredge data (Auffret et al., this volume) and seismic reflection profiles allow reconstruction of the topography of the sea floor at the end of rifting in Aptian time.

The most striking features allowing this reconstruction are horizontal planes which cut, in some areas, the crest of the tilted blocks, and indicate subaerial or shallow submarine erosion. Those erosional surfaces are shown on Figure 17 in light gray stippling. They extend much closer to the oceanic-continent boundary off Goban Spur than in the Meriadzek-Trevelyan area where the closest point to the boundary is near Site 401 .

The age of this erosional event is given by Hole 401 and by data on the shelf. At Site 401 (Figure 10A), outer shelf chalks of late Aptian age rest above shallow water carbonates of Late Jurassic and possibly earliest Cretaceous age; this demonstrates that erosion occurred during pre-Aptian time while rifting was active, i.e., while blocks were rotating . Near the shelf edge (Figure 16), correlation of seismic lines from data of the Western Approaches Basin demonstrates also that the Aptian-Albian rests on the erosional surfaces cutting the faulted blocks. The erosional planes, therefore, delineate areas on the continental margin which were at zero level during rifting. Figure 17 shows that a large part of the margin in front of the Western Approaches Basin was below this level. However, results from dredging and Site 402 show areas where no erosion occurred but were, nevertheless, under shallow water during Aptian time. On Figure 23, stars represent dredings where, in places, shallow water Aptian/ Albian sediments were recovered. At Site 402, Aptian/ Albian black shales were deposited as a prograding shelf on a subsiding shallow platform. Surfaces in gray stippling represent areas which were at zero level or at less than 200 meters depth during Aptian time. On this map it appears that, in front of the Aptian shelf, one or several isolated shallow banks existed in the area of Meriadzek. Outside these areas, water was deeper. At Hole 400A, Aptian/Albian sediments are interpreted as deep water sediments deposited not far from the CCD. Since post-rifting sediments, including Formation 3, are not faulted, the depth at which Aptian sediments were deposited at Site 400 can be estimated from the throw of the faults along the Meriadzek escarpment, i.e., from the difference of altitude between the Aptian at Site 401 and Site 400 .

A depth of 1500 to 2000 meters is indicated for the area of Hole $400 \mathrm{~A}$ on Trevelyan Plateau at the end of rifting. In front of the Western Approaches Basin, large areas of the submarine rift system were deep and a central trough of about 2000 meters depth existed. At the same time, most of the Goban Spur area was much shallower because erosional surfaces are observed relatively close to the continental/ oceanic boundary (Figure 17). Only a narrow deep trough existed there at the end of rifting. This change of style 


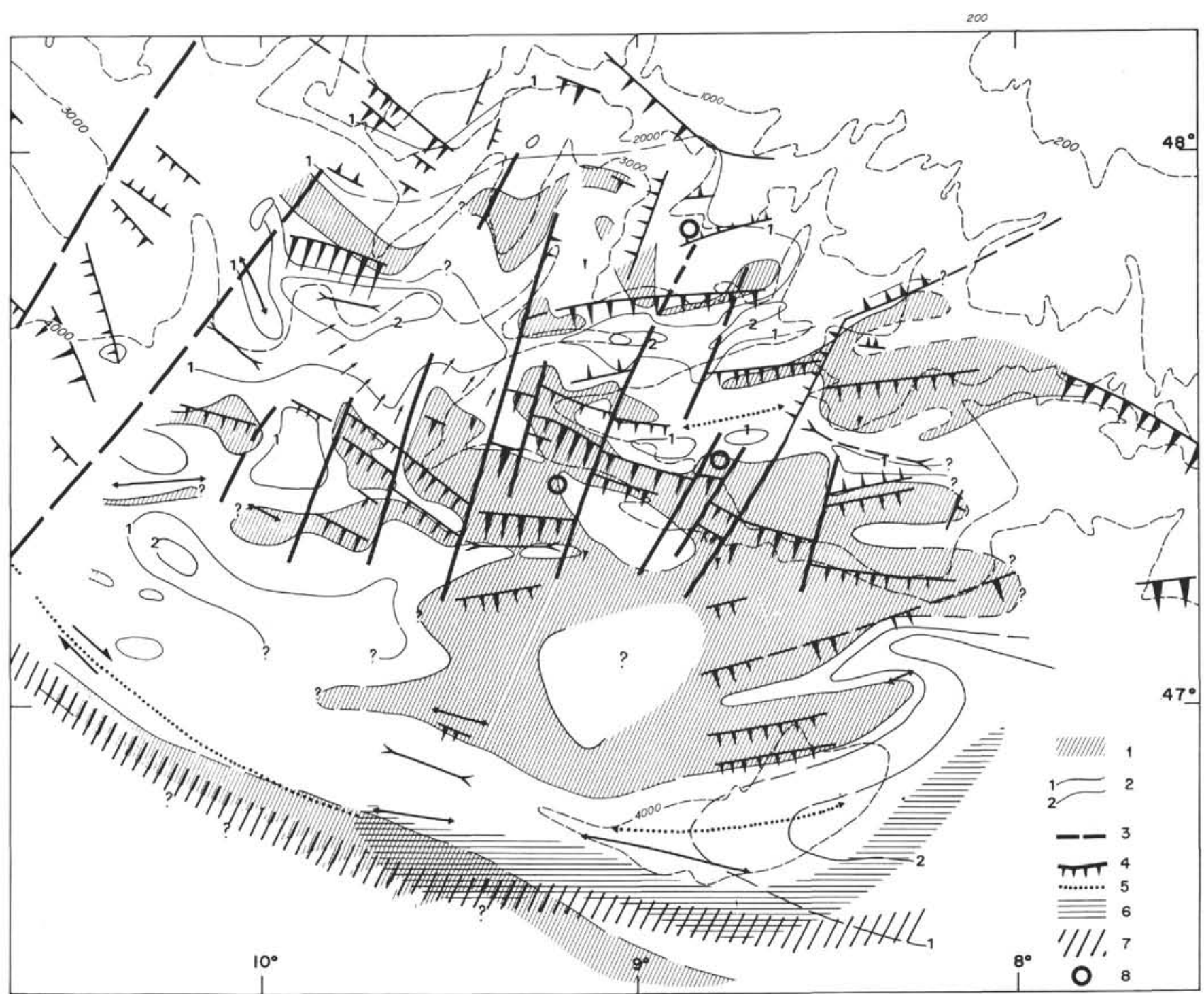

Figure 21. Rift tectonic pattern in the Meriadzek-Trevelyan area: $1=$ Pre-Aptian syn-rifting sediments absent or condensed; $2=$ Isopaches of syn-rifting pre-Aptian sediments in seconds two-way travel time; $3=$ Faults; $4=$ Listric faults with arrows down dip; 5 = Late Eocene strike slip faults or folds; $6=$ Tectonized area along Trevelyan escarpment resulting from late Eocene compression; $7=$ Continental/oceanic crusts boundary; $8=$ Sites 400, 401, 402 .

between the two areas may be explained by the difference in nature of the pre-rift rocks. On Goban Spur, rifting affected a Hercynian granitic basement without sedimentary cover, but in the Meriadzek area rifting affected a Hercynian basement probably of a different nature and covered by a thick Mesozoic sequence. This would suggest that the physiography of a rift system may be largely controlled by the nature of the pre-rift rocks.

\section{Discussion on Rifting and Attenuation}

Although rift tectonics are relatively simple, there is continuing controversy about their nature and development. Structural models are based mainly on the studies of continental subaerial rift systems like the east African rifts, the Rhine graben, the Suez rift, etc.

A common hypothesis is that intracontinental rifts are related to doming of the continental crust (Closs, 1939) and the following stages have been recently proposed (Neugebauer, 1978): (1) upwarping of the crust, (2) incipient volcanic activity, (3) formation of faults and increasing volcanic activity, and (4) subsidence of the graben. Burke and Whiteman (1972) considered also that rifts developed on crest of uplifts interpreted as isostatic responses to mass deficiencies produced by partial melting of the mantle above rising plumes at the base of the lithosphere. Freund (1965) pointing out the difference in width between the different rifts, the presence or absence of a swell, proposed a necking hypothesis with thinning of the crust below, accompanied by rising of the mantle. He also raised the question of the spatial and temporal relations between the rifts and the orogenies. Artemjev and Artyushkov (1971), from a study of the Baikal rift, proposed a mechanism resulting from crustal extension when neck-shaped strains in the crust are developed. The lower part of the crust is plastically attenuated and faults occur 
TREVELYAN

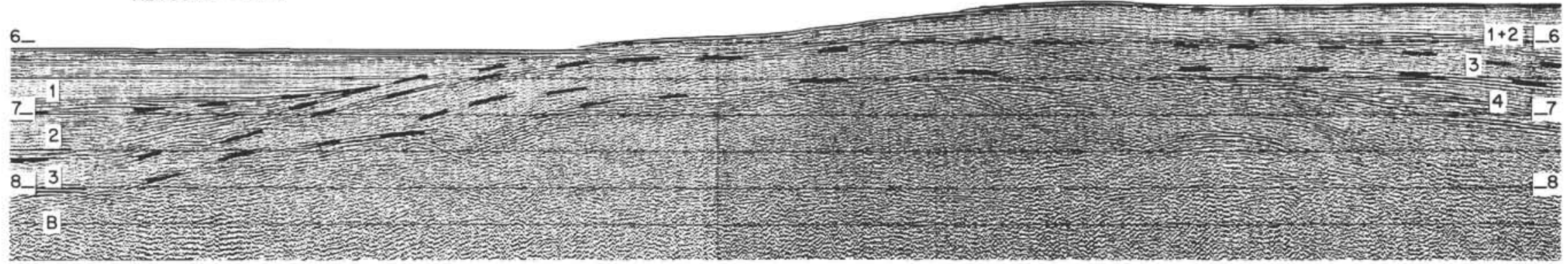

Figure 22. Correlation between Trevelyan and the abyssal plain showing existence of Formation 3 (Aptian/Albian) or the oceanic crust to the left. Note the thickening of Formations 1 and 2 in the abyssal plain. Trevelyan Formations 1 and 2 are pelagic, and in the abyssal plain they are most probably turbidite. 


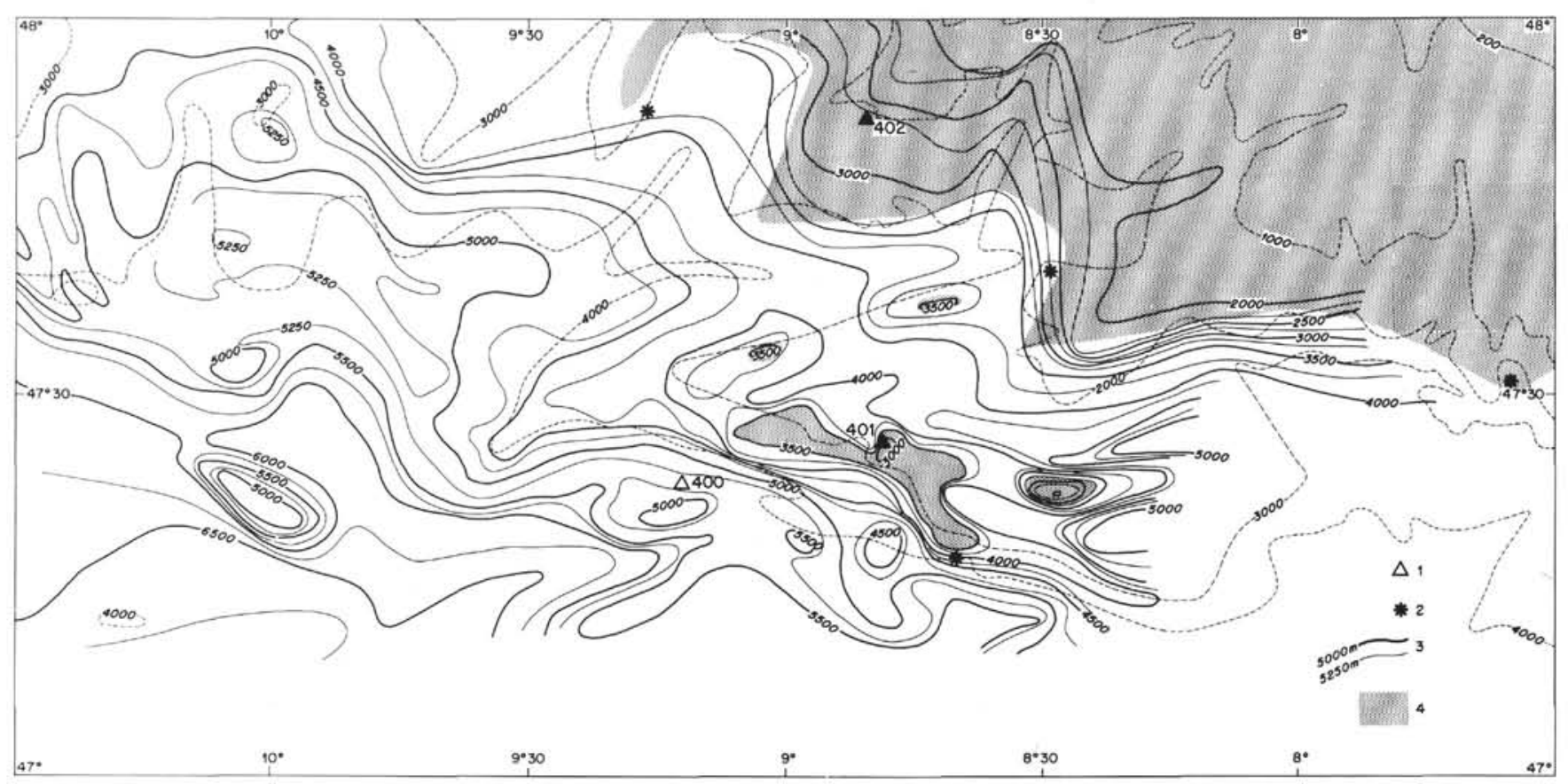

Figure 23. Shallow water areas during Aptian time. $1=$ Leg 48 drill sites; $2=$ Aptian-Albian shallow water sediments from dredging; 3 = Isobaths of base of Formation 3 (Aptian-Albian) i.e., of post-rifting sediments draping the topography inherited from rifting; $4=$ Areas which were at sea level or at shallow depth during Aptian time. Note the isolated shallow banks on Meriadzek.

in the upper layer of the crust where the viscosity is too high. Fuchs (1974) proposed a somewhat similar model for the Rhine graben.

The cause of crustal extension is also a matter of controversy. Heiskanen and Vening-Meinesz (1958) proposed large-scale movements in the mantle created by thermal convection, while Artemjev and Artyushkov (1971) suggest gravity convection. Others relate rifting to the stress field existing inside plates as a consequence of collisions (Illies, 1975; Garfunkel and Bartov, 1977).

Data on rifting from the study of continental margins are relatively scarce because the rift structures are often covered by a very thick sedimentary overburden hiding the deep structures. This difficulty is partly overcome on the starved north Biscay margin.

Leg 48 results and seismic reflection profiles demonstrated that in this area rifting was submarine in contrast to many rifts (Montadert, Roberts, etal., 1977) and occurred on a pre-existing Mesozoic sedimentary basin perhaps shaped during an earlier Triassic tensional episode (Winnock, 1971). Although the onset of rifting is not well established, comparison with Aquitaine Basins suggests it may have begun by Late Jurassic but was probably mainly active during the Neocomian. The end of rifting and the onset of spreading are very probably intra-Aptian. As demonstrated in the previous section, a broad, 2000-meter-deep trough existed at that time in the part of the margin southeast of the Goban Spur. This fact and the tectonic style observed with tilted blocks including the upper part of the continental crust, bounded by listric faults, are characteristic of an extension of the crust with the synchronous development of a central trough. Under continuing extension, the fault blocks can rotate only because the central trough is subsiding, so that individual blocks dip away from the axis. In the trough, the continental crust affected by listric faults was about 6 to $8 \mathrm{~km}$ thick; the rotation of the blocks reduced this thickness to about 4 to $5 \mathrm{~km}$ (Figure 18).

We suggest that the mechanical discontinuity which controlled the level, above which continental crust was faulted during rifting, corresponds to the transition between the upper brittle and the lower ductile continental crust (Griggs and Handin, 1960). This boundary is close to a strong horizontal reflector, situated at about $10 \mathrm{~km}$ below sea level, which corresponds to an increase of velocities from 4.9 to $6.3 \mathrm{~km} / \mathrm{s}$ as shown by refraction data. The Moho discontinuity was determined at $12 \mathrm{~km}$ below sea level. These results demonstrate an almost complete thinning of the ductile continental crust, reduced to $3 \mathrm{~km}$ as a maximum, by some sub-crustal processes, whereas it was probably about 15 to $20 \mathrm{~km}$ away from the rift (Figure 24). Recent heat flow data obtained in north Biscay margin (Foucher, this volume) support this mechanism of thinning of the ductile part of the continental crust and not transformation of the continental crust by phase changes or intrusion.

The amount of horizontal extension can be estimated approximately for the upper part of the continental crust. For rotation of $20^{\circ}$ to $30^{\circ}$ of the blocks, the extension of the area between the present shelf edge and the oceanic/continental crusts boundary is around 10 to 15 per cent of the previous width.

Also relevant to the rifting process is that no erosion occurred before and during rifting in the central trough of the rift system. In this case, rifting was not preceded by and therefore is not a consequence of a large doming. The same observation was made in the Rhine graben and in the Suez rift where more or less complete pre-rift sedimentary layers are 


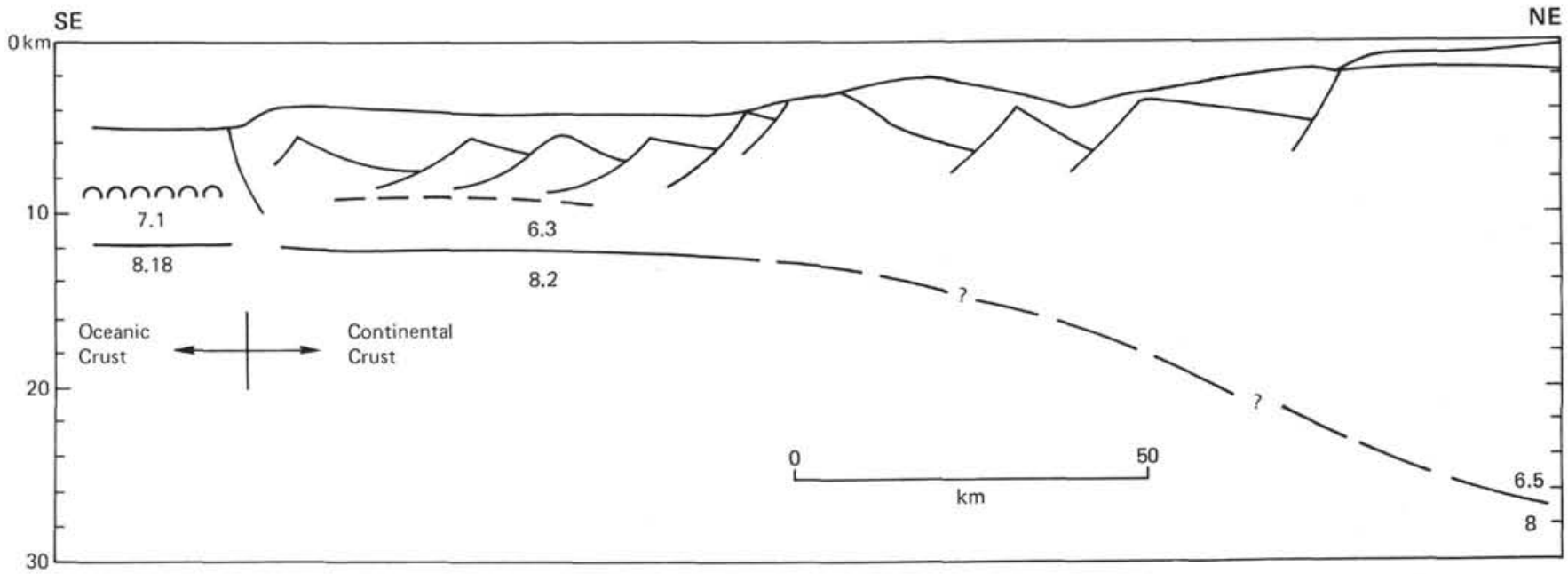

Figure 24. Schematic crustal section through the continental margin of north Biscay. Refraction data are from Avedik et al. (this volume) and Bott and Watts (1971).

preserved. The uplifting of the shoulders of the rift there post-dates the initiation of the graben. Such uplifting occurred also in Biscay away from the rift trough, but is not expressed in the topography because erosion kept pace with the uplift and maintained the area at the level of the sea. The cause of the uplift of the shoulders of the rift could well be regional isostatic adjustment.

From our observations, therefore, the most appealing mechanism for rifting would be stretching of the lithosphere as a response to intraplate stresses. These stresses could be due to the difference between the absolute velocities of plate boundaries or consequences of continental collisions (Forsyth and Uyeda, 1975). The stresses were applied to a crust made of two layers of completely different mechanical properties. As shown above, the extension is limited, but the thinning of the ductile part of the crust is much more important than the thinning of the brittle part by rotation of blocks. One must therefore conclude that there was decoupling between the two sections of the crust. Rock mechanics experiments (Poulet, 1976) show that strain of ductile material increases continuously when a certain level of stress is attained (viscous behavior). In contrast, the continuous strain of brittle material is relatively limited for increasing stress until a fracture is created which releases the stress. For this reason, it is quite possible that thinning of the ductile part of the crust began before the creation of the first fault in the brittle crust. Speculating that tensile stresses are the same at the lateral boundaries of the whole lithosphere, the extension will be more important in the lower ductile part by continuous viscous flow starting at a low level of stress than in the upper part where the process is a succession of stress accumulation and stress relaxation by faulting, until complete break-up of the lithosphere occurs. The continuous necking of the lower ductile part of the crust is accompanied by rising of the mantle and a depression in the upper brittle crust (the rift trough) which allows rotation of blocks along listric faults. In this model, elevation of isotherms under the rift is more a consequence of the necking of the crust than the cause of the rifting process (plume).

\section{The Post-Rifting History}

Complete rupture of the lithosphere occurred at the end of rifting in Aptian time, and new oceanic crust accreted along the young continental margin which began to subside.

Several mechanisms have been proposed for explaining this subsidence of the continental margins (Poulet, 1977). Sleep (1971, 1973), and Sleep and Snell (1976) suggested that post-rifting subsidence could be related to thermal contraction of the lithosphere which occurred when the heat source moves away from the margin after onset of spreading. Bott (1971, 1973) and Bott and Dean (1972) suggested that, accompanying or following the thermal contraction of the lithosphere, subsidence could occur as an isostatic response to crustal thinning caused by hot creep of lower continental crustal material towards the sub-oceanic mantle. This would be due to instability of young continental margins because of gravitational energy associated with the junction between oceanic and continental crust that would create wedge subsidence in the upper brittle layer. Walcott $(1970,1972)$ explained subsidence of the continental margin under loading by sediments by flexure of the lithosphere.

On the starved north Biscay margin, the post-rifting sediments are so thin that the influence of loading on subsidence is negligible and the fundamental mechanism of subsidence of a passive continental margin can be directly studied.

\section{Transition Between Continental and Oceanic Crusts}

The transition between continental crust and oceanic crust is relatively well documented by geophysical data. The magnetic anomaly map of the total field presented here (Sibuet, in preparation) (Figure 25) covers an area from the shelf of the Western Approaches to the center of the Bay of Biscay. The continental shelf is characterized by strong amplitude anomalies (Hill and Irvine, 1965; Segoufin, 1975; Le Borgne and Le Mouël, 1970) which do not extend off the shelf break. On the continental slope, anomalies of 


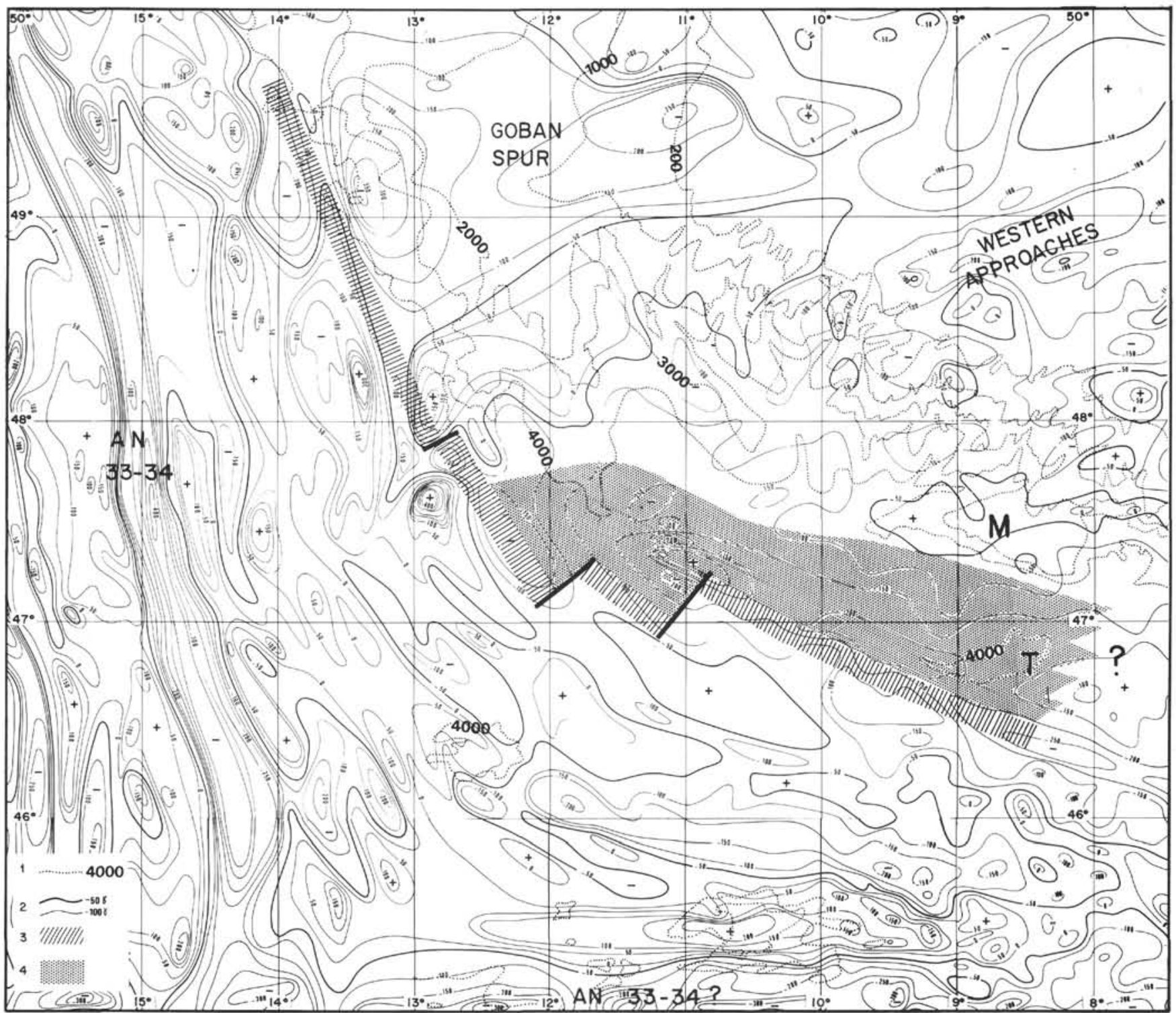

Figure 25. Magnetic anomalies of the total field (Sibuet et al., in preparation) from aeromagnetic map of Biscay (from Le Borgne and Le Mouël, 1970) and marine magnetic profiles from CNEXO-COB, IFP, Cambridge University, NIO, IOS, Bedford Institute of Oceanography, Durham University, LDGO, Netherlands Hydrographic Department (NA VADO Project). $1=$ Bathymetry from Berthois, $2=I$ sogam, $3=$ Hachured areas = oceanic $/$ continental crusts boundary, $4=$ Dotted areas $=$ thin continental crust with reflector below the tilted blocks.

generally small amplitude are oriented parallel to the margin with some transverse discontinuities which can be linked with transverse faults of the rift pattern. Northward, gravity and magnetic anomalies allowed to extend the batholitic axis of southwest England to the shelf break (Hill and Irvine, 1965; Day and Williams, 1970; Sibuet, 1972). The map shows that this axis extends to the foot of the continental slope where a late Hercynian granodioritic complex has been found by dredgings (Pautot et al., 1976). The oceanic domains of the Porcupine abyssal plain and of the Bay of Biscay are characterized by magnetic anomalies often of strong amplitude and small wavelength, shown as wellmarked lineations, respectively, oriented south-southeast to north-northwest and east to west to east-southeast to westnorthwest. In the Porcupine abyssal plain, the first clearly identified anomalies may be anomalies 33-34 (Cande and Kristoffersen, 1977) of latest Cretaceous age (van Hinte, 1976). Although interpretation of magnetic anomalies in Biscay is still under discussion, it seems that the central anomalies of the Bay, oriented east-west and superimposed on the north and south Charcot and Biscay seamounts, can be identified as anomalies 33-34 (Cande and Kristoffersen, 1977). This would imply that a triple point was active during the last phase of opening of the bay (Williams, 1975). However, the Biscay seamounts are extensively tectonized and this interpretation may not be correct (Roberts, to be published). Lineations existing between the anomalies 33-34 and the margin indicate the existence of an oceanic crust of pre-Senonian age (anomaly 34, $80 \mathrm{~m} . \mathrm{y}$.) (Alvarez et al., 1977; van Hinte, 1976). The lineations are not con- 
tinuous, but they do exist. They have been delineated mainly from the correlation between profiles of three small positive anomalies. The anomalies inside the "quiet zone", may be small reversals as observed for example in the Albian of Hole 400A (Hailwood et al., this volume). This is in good agreement with geological data on the margin that indicates an Aptian age for the end of rifting. Nevertheless, it must be pointed out that anomaly $M O$ of Aptian age is not found along the margin and accretion of new oceanic crust just after anomaly $M O$ cannot be excluded. At the foot of the margin, the transition from continental crust to oceanic crust is delineated from the gravity and magnetic profiles (Figure 26) and from seismic reflection profiles (Figures 27, 28,29 , and 30 ). In the northwest part of the margin, this boundary follows the base of the continental slope from Porcupine Sea Bight as far as the southern end of Goban Spur. The boundary is linear and sharp along Goban Spur (Figure 27). South of Goban Spur, the transition is also sharp (Figure 28); Hercynian granites have been dredged on the northeasternmost tilted block and oceanic crust is seen about $10 \mathrm{~km}$ to the southwest. In this case, magnetic anomaly amplitudes begin to increase already below the very attenuated continental crust. Southeastward, the boundary is shifted northward and it is close to a localized positive magnetic anomaly of strong amplitude (more than $400 \gamma$ ). Along the Trevelyan escarpment, it follows a large negative magnetic anomaly $(250 \gamma)$ which extends far to the southeast where it is superimposed on the north Gasgony Ridge (Grau et al., 1973; Montadert et al., 1976) which is the southern limit of the thick Armorican marginal basin. On Figure 29, a thick sequence of syn-rifting sediments whose deposition was controlled by a fault along the ocean/ continent boundary is shown. It should be noted that the throw of this fault is in an opposite direction to the listric faults bounding the tilted block on the margins. This feature seems to be frequently observed at the ocean/continent boundary, e.g., on west Rockall margin.

Seismic reflection data do not show evidence of Formation 3 (Aptian-Albian) on the oceanic crust west of the Goban Spur, but it is present along Meriadzek (Figure 22). This may indicate that the opening along Goban Spur was slightly younger than to the south. The nature and origin of the Armorican marginal basin north of the north Gascony Ridge are also raised by these results. It is either a piece of pre-Aptian oceanic crust covered by a thick Mesozoic sediment or it may be thinned continental crust as at Trevelyan, covered by a much thicker layer of Lower Cretaceous sediments.

\section{The Post-Rifting Subsidence}

Significant faulting of the post-rifting sediments is absent and, only locally, late Eocene faults are observed which are linked to intra-European plate compression well known in Biscay and western Europe (see below). Post-rifting subsidence is thus characterized by an overall tilting of the margin in post-Aptian time with coupling between the oceanic and continental crust. The absolute subsidence of the margin after rifting therefore can be estimated by the difference between the altitude of the Aptian horizon at the end of rifting and today.

As shown in a previous section, data from Leg 48 drilling, dredgings, and constraints from seismic reflection profiles allow reconstruction of the topography of the sea floor at the end of rifting, and by subtraction of the present depth of Aptian calculation of the absolute subsidence. The results are presented on a simplified section (Figure 31) through the best documented area of the margin from the shelf edge to the continental/oceanic crusts boundary.

Although post-rifting sediments are only a few hundred meters thick, an isostatic correction has been applied to the Aptian horizon for a local loading on an Airy-type crust (see for example, Watts and Ryan, 1975). It has been noted that calculation applied point by point may be in error when the thickness of sediments varies rapidly. This is particularly evident when the correction is made for horizontal erosional surface covered by more or less thick sediments. A mean thickness of sediments and a mean correction for the whole surface must be calculated. If such a correction is applied for individual surfaces, one could expect vertical differential movements between individual blocks caused by differential loading. Since we do not observe any such readjustments, one can conclude that the local loading affects a much larger area. Moreover, because the post-rift sediments are very thin, we do not observe flexuration; in fact, a single mean correction can be applied for the whole margin.

From Figure 31, it is inferred that the present depth attained by a point on the margin depends on its altitude at the end of rifting and on its distance from the ocean/continent boundary, while the absolute value of subsidence depends only on the distance to the ocean/continent boundary. It should be noted that estimation of the subsidence of a margin requires knowledge of the topography at the end of rifting which may be difficult to determine. This diagram confirms that a good coupling existed between the continental and oceanic crusts because, near the boundary, the continental crust subsided practically as much as the adjacent oceanic crust. Sleep (1971) suggested that due to cooling of the lithosphere, the subsidence rate would decay exponentially with time and that the time constant of subsidence would be similar to the time constant of subsidence of midocean ridges, i.e., $50 \mathrm{~m} . \mathrm{y}$. Figure 31 shows that for the same period of time, about $120 \mathrm{~m} . \mathrm{y}$. since Aptian, the amount of subsidence is not the same for every point of the margin, so that the time constant cannot be the same for the whole margin if temporal subsidence decreased exponentially. Only in the lower part of the margin is the constant similar to the one of the oceanic crust. There is, therefore, not a single law that characterizes the subsidence of a whole margin, but one law for each point.

The exponential decay of the subsidence rate with time for different points on the margin can be checked from paleodepth estimates for different periods of time after Aptian. In the case of Biscay, these curves cannot be drawn with precision since paleodepth estimates from paleontological data are less and less precise for increasing water depths and for increasing ages. Paleodepths estimates for the Mesozoic (Dupeuble, this volume) and for Cenozoic (Schnitker, this volume) nevertheless support an exponential decay especially at Site 401, although elsewhere there is no contradiction with the paleontological and sedimentological data (Figure 32).

In the lower part of the margin where the continental crust is thin, the subsidence rate is not too different from the 


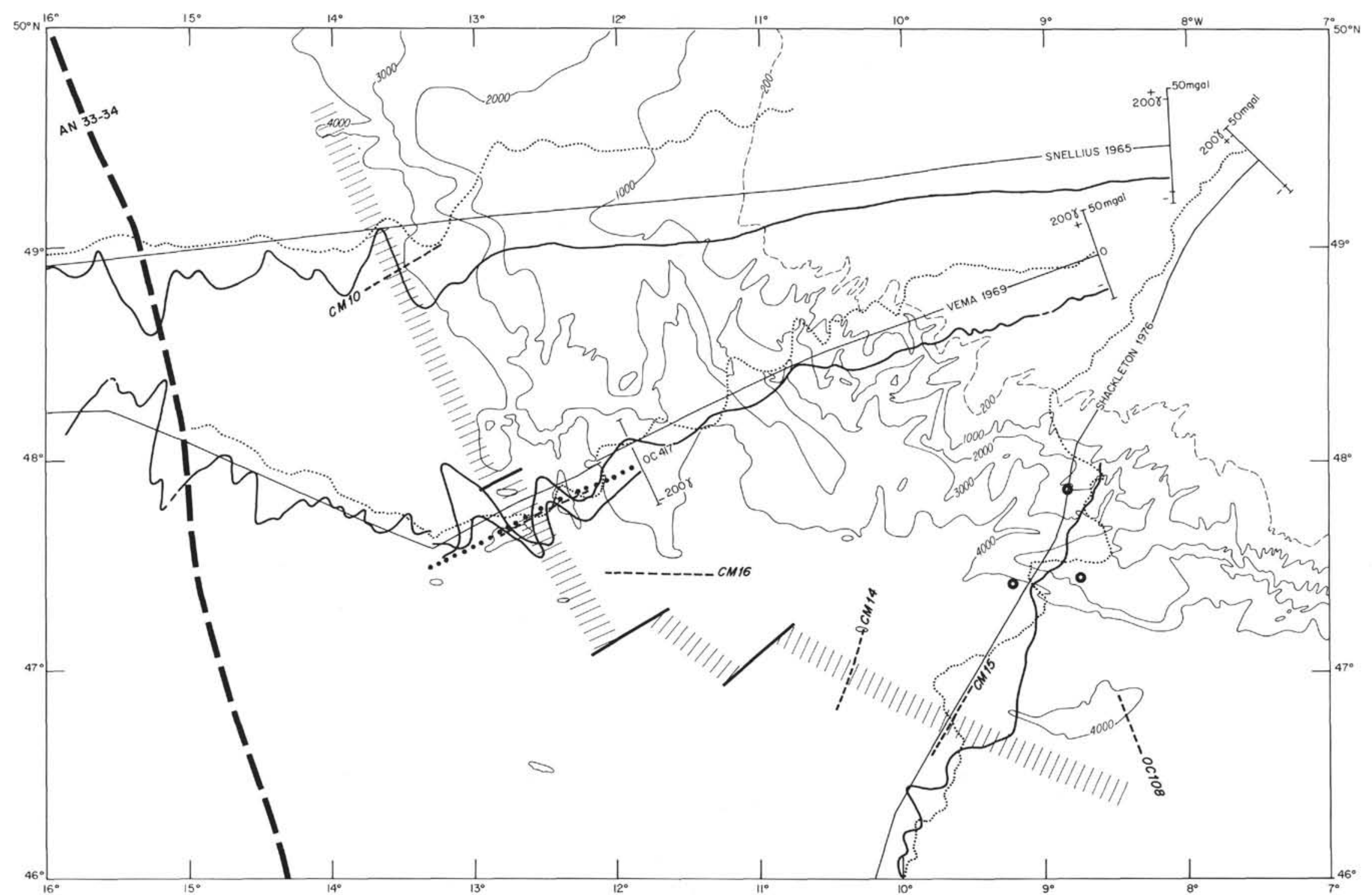

Figure 26. Magnetic and gravimetric profiles through the north Biscay margin. Hatching indicates oceanic/continental crusts boundary. CM, OC seismic profiles presented in this paper. 


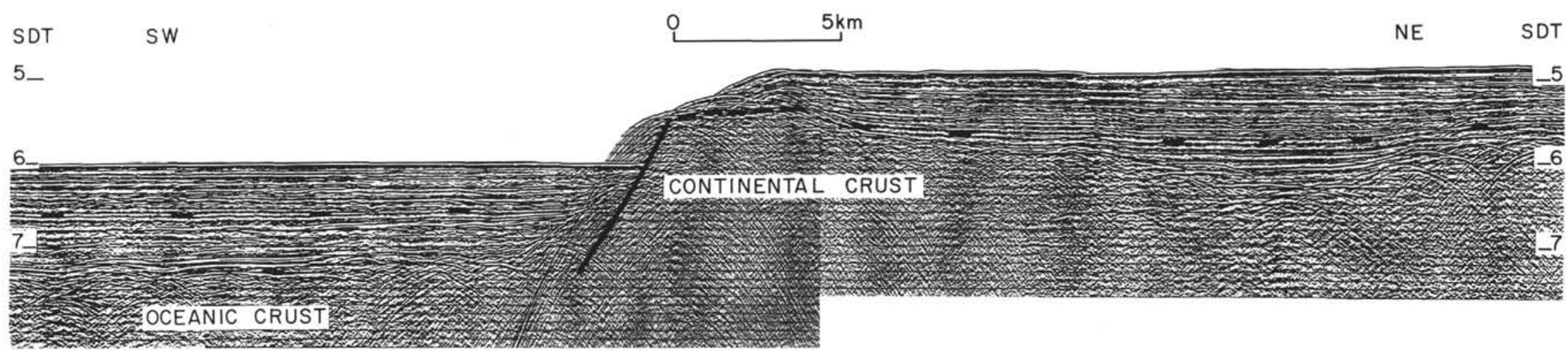

Figure 27. Oceanic/continental crusts transition along Goban Spur. Profile CM 10, processed. See location on Figure 25.

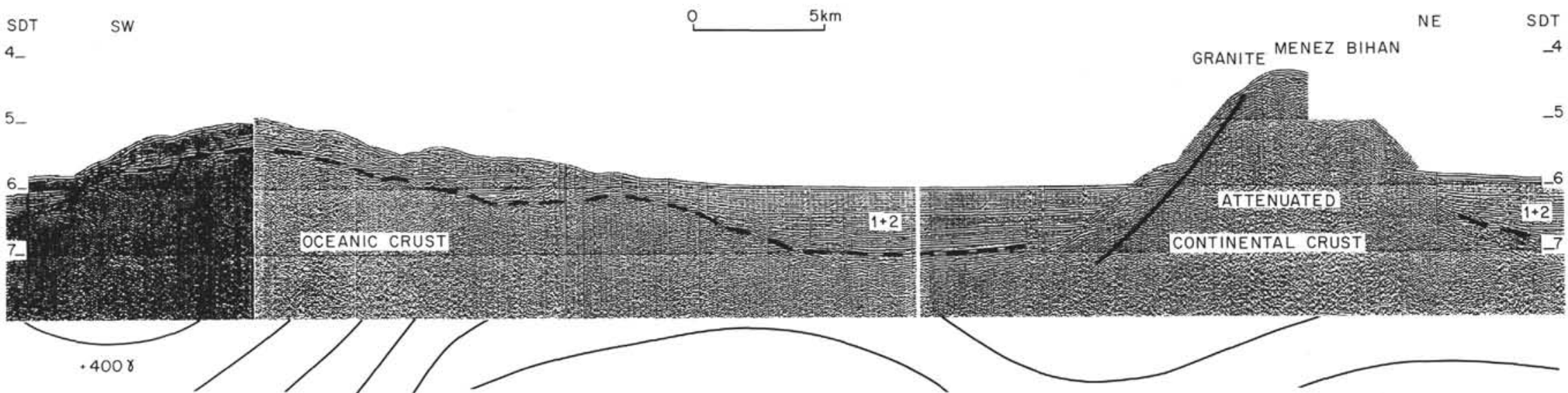

Figure 28. Continental/oceanic crust transition south of Goban Spur (see location, Figure 26). Granites have been dredged on the block to the right. Note that magnetic anomalies began to increase immediately below the thin continental crust. Profile OC 417, unprocessed. 
6

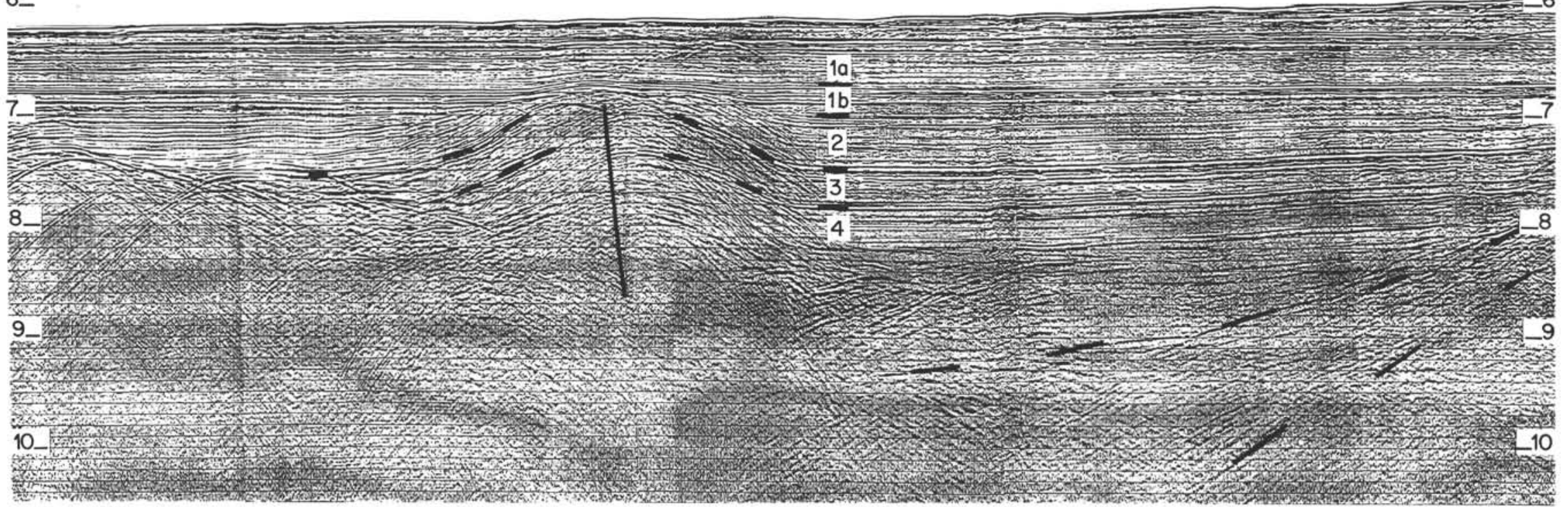

Figure 29. Transition from continental to oceanic crust. Note the thick sequence of syn-rift sediments controlled by a fault along the boundary but in opposite direction of the listric faults on the margin. A late Eocene fault interpreted as a strike-slip fault followed the boundary. See location on Figure 26. Profile CM 14 , processed. 
6
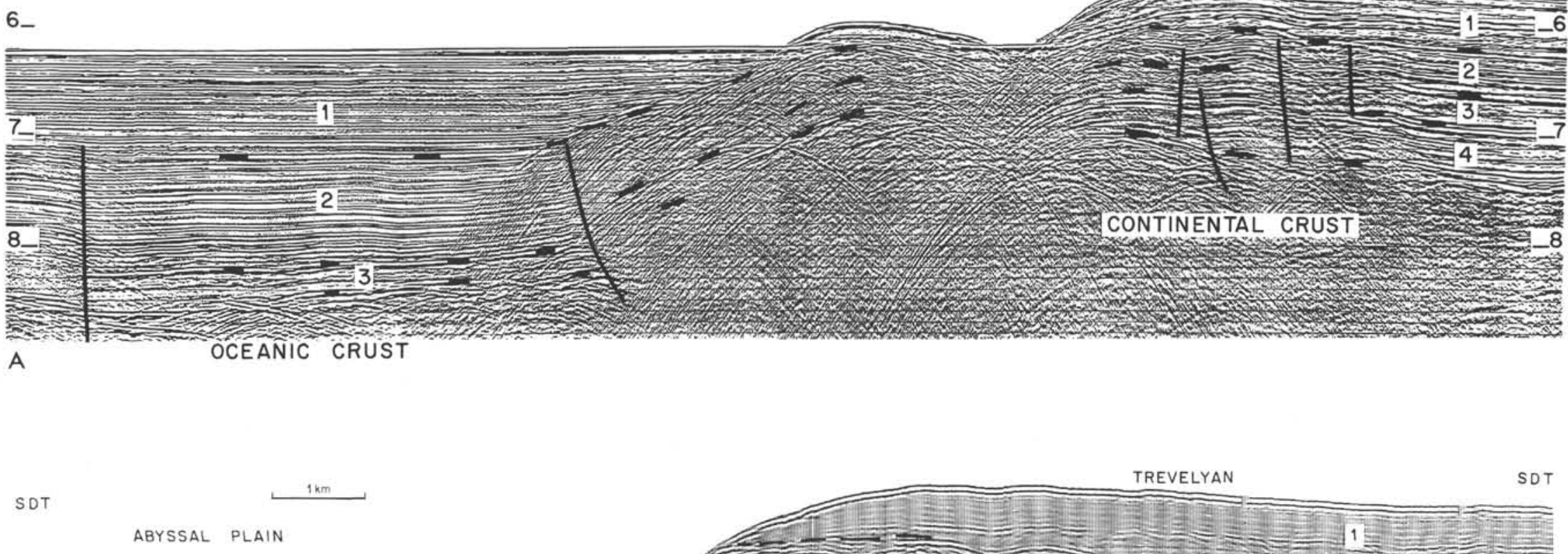

6.

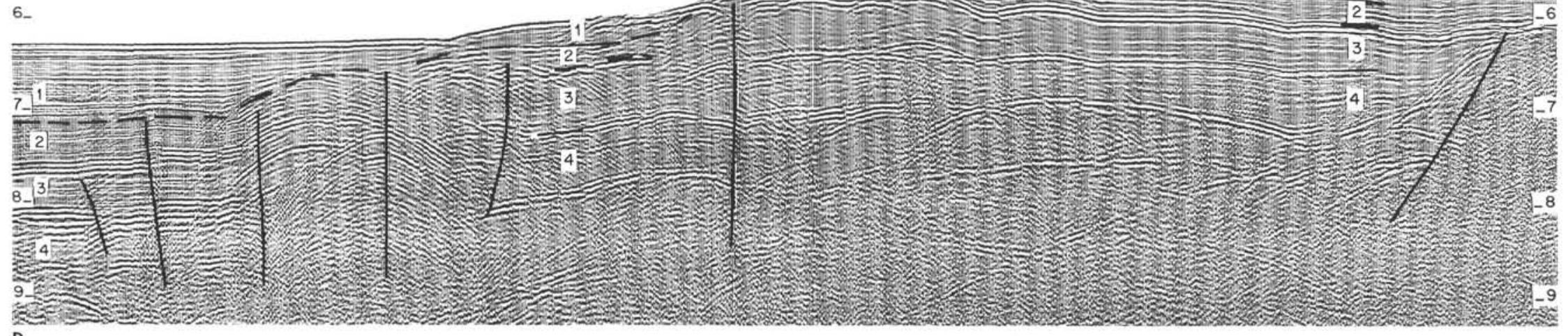

B

Figure 30. (A) Seismic profile across Trevelyan escarpment through oceanic/continental crust boundary. The escarpment is due to late Eocene compression. Formation 3 is Aptian-Albian. Formation 2 is Upper Cretaceous to upper Eocene. Note Formation 3 on oceanic crust. Profile CM 15, processed (see location on Figures 2 and 26). (B) Seismic profile across southeast Trevelyan escarpment. The escarpment is due to late Eocene compression. Note the great thickness of sediments below Formation 3, characteristic of the deep Armorican marginal basin. Profile OC 108 processed (see location on Figures 2 and 26). 


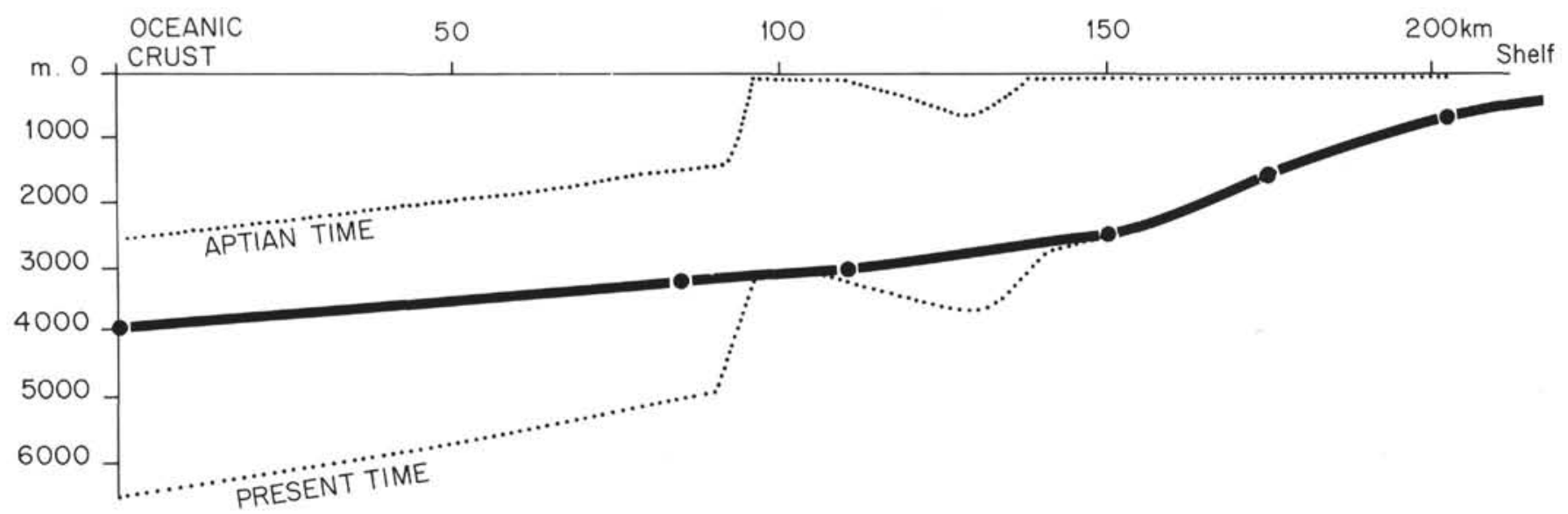

Figure 31. Absolute amount of post-rifting subsidence of north Biscay margin from the shelf to the oceanic crust. Upper dotted line $=$ simplified topography of the rift at Aptian time. Lower dotted line $=$ present depth of Aptian corrected for loading. Full line = amount of subsidence.

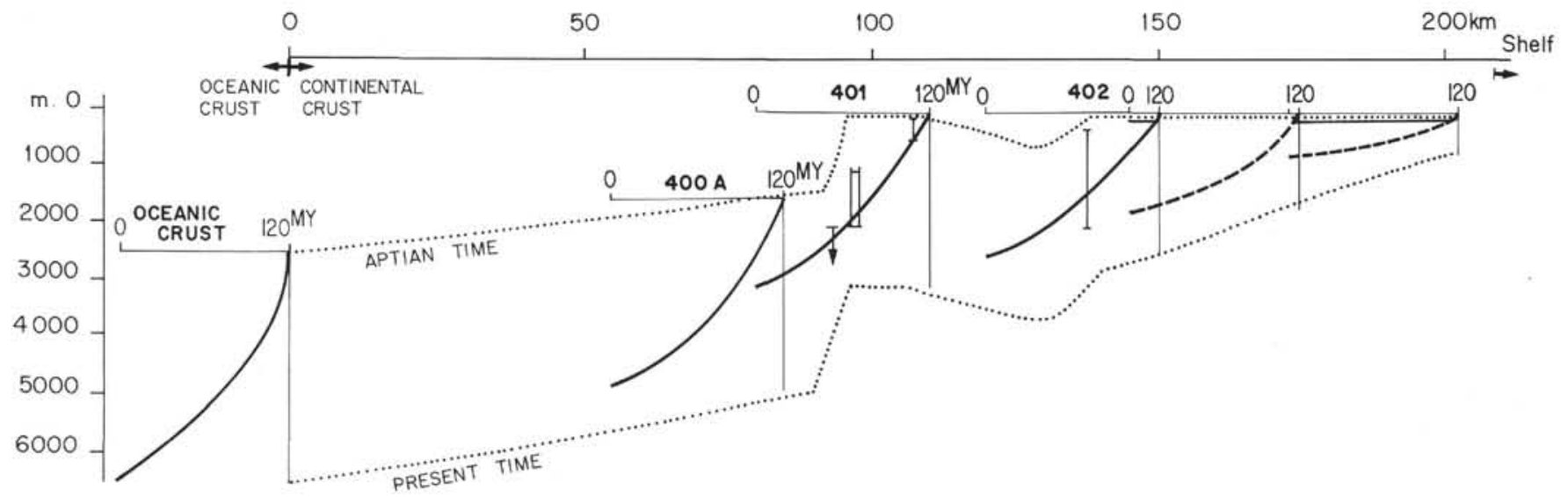

Figure 32. Hypothetic subsidence versus time curves for different areas of the margin from shelf to oceanic crust. Upper dotted line $=$ simplified topography of the rift at Aptian. Lower dotted line $=$ present depth of Aptian corrected for loading.

subsidence rate of the adjacent oceanic crust, but towards the shelf, with increasing thickness of continental crust, the subsidence rate diminishes considerably. Changes of slope on the subsidence versus distance curve (Figure 31 ) probably reflect a sharper change in thickness of the continental crust (Figure 24). It is therefore suggested that post-rifting subsidence without influence of loading is essentially an isostatic adjustment to cooling of the lithosphere in which the continental crust has been previously thinned during the rifting process. In that case, one can expect a relationship between the absolute subsidence of a point on a margin and the thickness of the continental crust.

\section{The Cenozoic (Eocene) Deformations}

In north Biscay we observed that often rifting of the margin subsidence occurred, regionally tilting the margin. Rejuvenation of the rift faults is not observed to have taken place during this period, although it may occur on other margins due to differential loading under a thick sedimentary cover. The absence of tectonic activity is in good agreement with the position of the north Biscay margin within the European plate during Cenozoic time.
Nevertheless, to the south, the northern edge of Iberia was a plate boundary where some subduction of Biscay oceanic floor occurred at least until late Eocene. Eastward, towards the Mediterranean area, Europe was in collision with Africa. Under such conditions, intra-plate deformations can occur and indeed have been described both in the oceanic and continental parts of the European plate.

In the oceanic area, north of the tectonized area (Figure 1) along Iberia, numerous areas uplifted during late Eocene can be defined (Montadert and Winnock, 1971; Grau et al., 1973; Montadert et al., 1974) from seismic reflection and drilling. On uplifted areas, thin pelagic post-Eocene sediments were deposited (DSDP Site 119, Laughton, Berggren et al., 1972) and are easily distinguished from turbidites deposited around the high points. Numerous faults of this age are also visible in the abyssal plain as well as on the continental margin. Their occurrence has led to overestimates of their role on the formation of the continental margin. On land, numerous studies show that deformation occurred in the whole continental domain at the same period (De Charpal et al., 1974) in France, England, and Germany. Another compressional event occurred since 
Miocene time but is restricted geographically to the north, in the southeastern part of the Paris Basin. The whole European plate was submitted to compression during late Eocene in the oceanic domain as well as in the continental one. Following orientation of the pre-existing structures, this compression created strike-slip faults, reverse faults, folds, etc.

New seismic profiles in the north Biscay margin allow a better estimate of the Cenozoic deformations. Faults are relatively restricted to some areas (Figure 17) the most striking features of which are observed along the Trevelyan escarpment. Along an east-west belt, numerous faults, including reverse faults, affected the series including Formation 2 (Figure 30); the faulting caused uplift that created the Trevelyan escarpment. This strongly tectonized east-west belt disappears progressively towards the northwest, as indicated by the disappearance of the escarpment, and merges into almost a single fault system oriented northwestsoutheast, which can be followed as far as the south of Goban Spur (Figure 17). The fault is interpreted as a strikeslip fault because of absence of vertical throw and deformation of layers on both sides as in drag folds (Figures 9 and 22). Other effects of late Eocene deformations include narrow elongated folds, broadly oriented east-west, on top and along the Trevelyan and Meriadzek escarpments (Figures $11,30)$. In a few cases, rejuvenation of rift faults is visible (Figure 7B). The Cenozoic deformations observed in this part of the margin accord with an almost north-south direction of Eocene lateral compression as determined on land.

Reverse faults and even some thrusting can be observed where a pre-existing, almost east-west, discontinuity existed in the basement. This is true for the Trevelyan Escarpment which is situated at the junction between the oceanic/continental crusts boundary and the important structural boundary separating the Western Approaches margin from the Armorican margin and the Armorican marginal basin (Figure 1). This is true also for the uplifted area oriented east-west in the center of Biscay, with some features like Cantabria Seamount which are controlled by a sharp east-west-oriented rise of the ocean crust. Where the discontinuities or inhomogeneities in the basement are oriented differently, for example, northwest-southeast as in the north Biscay and Armorican margins or the north Gascony Ridge in the central part of Biscay, the Eocene compression is marked essentially by faults with a strike-slip component.

\section{ACKNOWLEDGMENTS}

L. Montadert, O. de Charpal, and P. Guennoc are indebted to Institut Français du Pétrole, CNEXO and CEPM (IFP, SNEA [P], CFP) which permitted the acquisition of data, and their participation to Leg 48 studies. They are particularly grateful to the geophysicists (J. P. Fail, R. Donatien, and J. Cassand) and crew of the M.S. Florence of the Institut Français du Pétrole which collected the geophysical data in the Bay of Biscay before and after Leg 48 of the Glomar Challenger, and to several geologists (B. Soulhol, S. Oum, I. Aydinak, J. P. Esteve) involved in the preparation of the leg at IFP.

D. G. Roberts wishes to acknowledge the Department of Energy supporting acquisition of the seismic data after Leg 48 and his participation with Leg 48 studies.
The authors are grateful to M. Poulet (IFP) and J. C. Sibuet (CNEXO) for their many helpful suggestions and critical discussion of the manuscript.

\section{REFERENCES}

Alvarez, W. A., Fisher, A. G., Lowrie, W., Napoleone, G., Premoli-Silva, I., and Roggenthen, W. M., 1977. Upper Cretaceous-Paleocene magnetic stratigraphy at Gubbio, Italy-V-Type section for the Late Cretaceous-Paleocene magnetic time scale, Geol. Soc. Am. Bull., v. 88, p. 367-389.

Artemjev, M. E. and Artyushkov, E. V., 1971. Structure and isostasy of the Baikal rift and the mechanism of rifting, $J$. Geophys. Res., v. 76, p. 1197-1211.

Berthois, L. and Brenot, R., 1966. Cartes bathymétriques du talus du plateau continental en onze feuilles éditées par Berthois L. avec le concours du CNRS.

Berthois, L., Brenot, R., and Debyser, J., 1968. Remarques sur la morphologie de la marge continentale entre l'Irlande et le cap Finisterre, Rev. Inst. Franç. du Pétrole, v. 23, p. 1046-1049.

Blair, D. G., 1975. Structural styles in north sea oil and gas fields. In Woodland, A. W. (Ed.), Petroleum and the continental shelf of North-West Europe - geology: London (Applied Science Publishers Ltd.), v. 1, p. 327-338.

Bott, M. H. P., 1971. Evolution of young continental margins and formation of shelf basins, Tectonophysics, v. 11, p. 319-327. 1973. Shelf subsidence in relation to the evolution of young continental margins. In Tarling, D. H. and Runcorn, S. K. (Eds.), Implications of continental drift to the earth sciences: London (Academic Press), v. 2, p. 675-683.

Bott, M. H. P. and Dean, D. S., 1972. Stress systems at young continental margins, Nature, Phys. Sci., v. 235, p. 23-25.

Bott, M. H. P. and Watts, A. B., 1971. Deep structure of the continental margin adjacent to the British Isles. In Delany, F. M. (Ed.), The geology of the east continental margin $-2-$ Europe: London (Institute of Geological Sciences), Rept. 70/14, p. 93-109.

Bowen, J. M., 1975. The Brent oil field. In Woodland, A. W. (Ed.), Petroleum and the continental shelf of North-West Europe - geology: London (Applied Science Publishers Ltd.), v. 1, p. 353-362.

BRGM, ELF, Re, ESSO, REP, SNPA, 1974. Geologie du Bassin d'Aquitaine: Paris (BRGM Editions).

Burke, K. and Whiteman A. J., 1972 uplift, rifting, and the break-up of Africa. In Tarling, D. H. and Runcorn, S. K. (Eds.), Implications of continental drift to the earth sciences: New York (Academic Press), v. 2, p. 735-755.

Cande, S. C. and Kristoffersen, Y., 1977. Late Cretaceous magnetic anomalies in the North Atlantic, Earth Planet. Sci. Lett., v. 35 , p. $215-224$

Closs, H., 1939. Hebung-Spaltung-Vulkanismus, Geol. Rundsch., v. 30 , p. $405-527$.

Day, G. A. and Williams, C. A., 1970. Gravity compilation in the northeast Atlantic and interpretation of gravity in the Celtic Sea, Earth Planet Sci. Lett., v. 8, p. 207, 213.

De Charpal, O., Trémolières, P., Jean, F., and Masse, P., 1974. Un exemple du tectonique de plate-forme. Les Causse majeurs, Rev. Inst. Franç. du Pétrole, v. 29-5, p. 715-732.

Dingle, R. V. and Scrutton, R. A., 1977. Continental margin fault pattern mapped South West of Ireland, Nature, v. 268, p. 720-723.

Ewing, J. and Ewing, M., 1959. Seismic refraction measurements in the Atlantic Ocean basins: The Mediterranean Sea, on the Mid-Atlantic Ridge, and the Norwegian Sea, Geol. Soc. Am. Bull., v. 70 , p. 291. 
Forsyth, D. and Uyeda, S., 1975. On the relative importance of the driving forces of the plate motion, Geophys. J. Roy. Astron. Soc., v. 43, p. 163-200.

Freund, R., 1965. Rift Valleys, Can. Geol. Surv., Paper 64-14, p. 330-344.

Fuchs, K., 1974. Geophysical contributions to taphrogenesis. In Illies, J. H. and Fuchs, K. (Eds.), Approaches to Taphrogenesis: Stuttgart (Schweizerbart), p. 420-432.

Garfunkel, Z. and Bartov, Y., 1977. The tectonics of the Suez Rift, Geol. Surv. Israel Bull., no. 71

Grau, G., Montadert, L., Delteil, R., and Winnock, E., 1973. Structure of the European continental margin between Portugal and Ireland, from seismic data. In Mueller, S. (Ed), The structure of the earth's crust: tectonophysics, v. 20, p. 319-339.

Griggs, D. T. and Handin, J. (Eds.), 1960. Rock deformation, Geol. Soc. Am. Mem., 79, p. 1-382.

Heiskanen, W. A. and Vening-Meinesz, F. A., 1958. The Earth and its gravity field: New York (McGraw-Hill).

Hill, M. N. and Irvine, F. J., 1965. A preliminary magnetic survey of the Western Approaches to the English Channel, Quart. J. Geol. Soc. London, v. 121, p. 463-465.

Illies, J. H., 1975. Recent and paleo-intraplate tectonics in stable Europe and the Rhine graben rift system, Tectonophysics, v. 29 , p. $251-264$.

Laughton, A. S., Berggren, W. A., et al., 1972. Site 118 and Site 119. In Laughton, A. S., Berggren, W. A., et al., Initial Reports of the Deep Sea Drilling Project, v. 12: Washington (U.S. Government Printing Office), p. 673-901.

Le Borgne, E. and Le Mouël, J., 1970. Cartographie aéromagnétique du Golfe de Gascogne, C. R. Acad. Sci. Paris, v. 271D, p. 1167-1170.

Lowell, J. and Genik, G., 1972. Sea-floor spreading and structural evolution of the southern Red Sea, Am. Assoc. Petrol. Geol. Bull., v. 56 , p. $247-259$.

Lowell, J. A., Genik, G. J., Nelson, T. H., and Tucker, P. M., 1975. Petroleum and plate tectonics of the southern Red Sea. In Fischer, A. G. and Judson, S. (Eds.), Petroleum and global tectonics: Princeton (Princeton University Press), p. 129-153.

Montadert, L. and Winnock, E., 1971. L'histoire structurale du golfe de Gascogne. In Histoire structurale du golfe de Gascogne. Paris (Ed. Technip.), v. I-II, p. VI.16-1-VI.16-18.

Montadert, L., Damotte, B., Delteil, J. R., Valéry, P., and Winnock, E., 1971. Structure géologique de la marge continentale septentrionale du golfe de Gascogne (Bretagne et Entrées de la Mancye). In Histoire structurale du golfe de Gascogne: Paris (Ed. Technip.), v. I-II, p. III. 2-1-III. 2-22.

Montadert, L., Roberts, D. G., Auffret, G. A., Bock, W. O., Dupeuble, P. A., Hailwood, E. A., Harrison, W., Kagami, H., Lumsden, D. N., Müller, C., Schnitker, D., Thompson, R. W., Thompson, T. L., and Timofeev, P. P., 1976. Glomar Challenger sails on Leg 48, Geotimes, v. 21, p. 19-23. 1977. Rifting and subsidence on passive continental margins in the North East Atlantic, Nature, v. 268, p. 305-309.

Montadert, L., Winnock, E., Delteil, J. R., and Grau, G., 1974. Continental margins of Galicia-Portugal and Bay of Biscay. In Burk, C. A. and Drake, C. L. (Eds.), The Geology of continental margins: New York (Springer-Verlag), p. 323-342

Moore, J. M. and Davidson, A., 1978. Rifting structure on southern Ethiopia, Tectonophysics, v. 46, p. 159-173.

Neugebauer, H. J., 1978. Crustal doming and the mechanism of rifting Part I: Rift formation, Tectonophysics, v. 45, p. 159 186.
Pastouret, L. and Auffret, G.A., 1976. Observations sur les microfaciès des roches sedimentaires prélevées sur la marge armoricaine, Rev. Inst. Français. du Pétrole, v. 31, p. 401-425.

Pautot, G., Renard, V., De Charpal, O., Auffret, G. A., and Pastouret, L., 1976. A granite cliff deep on the North Atlantic, Nature, v. 263, p. 669-672.

Poulet, M., 1976. Apport des expériences de mécanique des roches à la géologie structurale des bassins sédimentaires, Rev. Inst. Franç. du Pétrole, v. 31, p. 781-822.

, 1977. Mécanismes de formation des bassins sédimentaires de marge stable, Bull. Centres Rech. Explor. Prod. Elf Aquitaine, v. 1-1, p. 131-145.

Rosset, R. A. and Dardel, R., 1971. Histoire geologique et structurale du bassin de parentis et de son prolongement en mer. In Histoire Structurale du golfe de Gascogne: Paris (Technip), v. IV, .2 , p. $1-28$.

Segoufin, J., 1975. Structure du plateau continental armoricain. In A discussion on the geology of the English Channel, Phil. Trans. Roy. Soc. London, v. 279, p. 109-121.

Sibuet, J. C., 1972. Contribution de la gravimétrie à l'étude de la Bretagne et du plateau continental adjacent, C. R. Somm. Soc. Geol. France, v. 24, p. 124-129.

Sleep, N. H., 1971. Thermal effects of the formation of Atlantic Continental Margins by continental break-up, Geophys. J. Roy. Astron. Soc., v. 24 , p. $325-350$.

, 1973. Crustal thinning on Atlantic Continental Margins: evidence from older margins. In Tarling, D. H. and Runcorn, S. K. (Eds), Implication of continental drift to the earth sciences: London (Academic Press), v. 2, p. 685-692.

Sleep, N. H. and Snell, N. S., 1976. Thermal Contraction and flexure of Mid-Continent and Atlantic marginal basins, Geophys. J. Roy. Astron. Soc., v. 45, p. 125-154.

Stride, A. H., Curray, J. R., Moore, D. G., and Belderson, R. H., 1969. Marine geology of the Atlantic Continental margin of Europe, Phil. Trans. Roy. Soc. London, v. 264, p. 31.

Tucholke, B. E. and Mountain, G. S., 1978. Lithologic correlation and significance of major seismic reflectors in the Western North Atlantic, Second Ewing M. Memorial Symp., March 19-25, 1978

van Hinte, J.E., 1976. A Cretaceous time scale, Am. Assoc. Petrol. Geol. Bull., v. 60, p. 498-516.

Vening-Meinesz, F. A., 1950. Les "graben" africains, résultats de compression ou de tension dans la croûte terrestre? Bull. Inst. R. Colonial Belge, v. 21, p. 539-552.

Walcott, R. I., 1970. Flexural rigidity, thickness and viscosity of the lithosphere, J. Geophys. Research, v. 75,10 , p. 39413954 .

, 1972. Gravity flexure and the growth of sedimentary basins at a continental edge, Geol. Soc. Am. Bull., v. 83, 6, p. $1845-1848$

Watts, A. B and Ryan, W. B. F., 1975. Flexure of the lithosphere and continental margins basins, Tectonophysics, no. 36, p. $25-44$

Williams, C. A., 1975. Sea-floor spreading in the Bay of Biscay and its relationship to the North Atlantic, Earth Planet. Sci. Lett., v. 24 , p. $440-456$.

Winnock, E., 1971. Géologie succincte du Bassin d'Aquitaine (contribution à l'histoire du Golfe de Gascogne. In Histoire Structurale du Golfe du Gascogne: Paris (Technip), v. IV, 1, p. 1-30. 